\title{
People think there's no nature in cities, but they want to know more
}

\author{
$\underline{\text { Natalia C. Piland }}^{1}, \underline{\text { Estrella Velásquez-Ruíz }}^{2}, \underline{\text { Cristina Palao-Lambarri }}^{3}, \underline{\text { Mario Caller }}^{4}$ and Xiomara A. Valdivia-Zavaleta $^{2}$
}

\begin{abstract}
We surveyed urban residents to study their knowledge, engagement, perception, and curiosity of bird biodiversity in four Peruvian cities in two different ecosystems (Lima and Huacho in the Pacific desert, and Nauta and Iquitos in the western Amazon). Surveys also included questions on social variables such as age, gender, education, outdoor activities, and years residing in the area. Bird point counts were carried out in the same sites where residents were surveyed. These sites were also visually assessed for greenspace cover and distance to nearest landmarks. Exploratory analyses (principal components analyses and factor analysis of mixed data) were carried out on environmental and survey data to summarize and select correlated variables for multivariate linear models. Amazonian city residents had higher "knowledge" and "engagement" scores than residents in the desert cities. Best performing models predicting "knowledge" scores suggested that urban residents learned about birds outside of the formal education sphere, although there were no strong common patterns among cities or in the full dataset. "Engagement" scores in the desert cities seemed to be linked to local and neighborhood greenspace and education, suggesting socioeconomic class plays a role. The overwhelming majority of all four cities' respondents scored highly in "perception" and "curiosity" measures, implying that orientation toward nature is not lost in these four cities and that finding and promoting the human-nature connection in urban areas is a matter of asking the right questions and promoting existing nature practices and perspectives.
\end{abstract}

Key Words: extinction of experience; human-nature connection; mixed methods; Peru; urban avian biodiversity

\section{INTRODUCTION}

Cities are full of people who can promote or subvert conservation and environmental priorities depending on their political and economic participation, attitudes, and connections with nature (Sanderson et al. 2018). When cities subvert conservation and environmental priorities, they encroach on arable land and natural habitat (e.g., Ewing 1997), support a human population with a higher demand for meat and other energy-intensive goods (e.g., de Haen et al. 2003), and negatively disrupt nitrogen cycling and microbial communities (e.g., Wang et al. 2017). By contrast, when they promote conservation and environmental priorities, cities have less energy use per capita than rural areas (Güneralp et al. 2017), house more people at a higher standard of living (Addanki and Venkataraman 2017), and present the opportunity to lay down a foundation for a smaller future impact on biodiversity (Sanderson et al. 2018). Thus, as the global population urbanizes, the human-nature connections of urban residents are a starting point toward understanding how humans lead the cities they live in on paths away from or toward sustainability.

Human connections with nature are influenced by the varied ways people relate to and value it (Chan et al. 2016). In cities, green spaces can provide direct benefits by promoting exercise (Wolch et al. 2014), providing new economic opportunities (Wolch et al. 2014), and serving as the setting for urban agriculture (Azunre et al. 2019). Cities also have trees mitigating the increased temperatures caused by urbanization (Derkzen et al. 2017, Lin and Gou 2017), wetlands purifying water for use as tap water (de Groot et al. 2002), and biodiversity decreasing the chance of human infection by a generalist pathogen (Hassel et al. 2017). The aesthetic quality of nature has promoted scientific literacy through natural history activities (Wood et al. 2011), and both green and blue (water) spaces have facilitated community development through mental well-being and social cohesion (Wolch et al. 2014, Corburn 2017).

However, many cities are concrete canyons, not urban forests. In these gray spaces, scholars have theorized that humans lose their connection to nature, thus the desire to conserve it, through "the extinction of experience" (Pyle 1978, as cited in Pyle 2003). This process states that as the species richness to which humans are exposed decreases, the power of nature to incite humans into action is lost (Pyle 2003). Research into what causes extinction of experience has been conducted in the United States, Japan, Spain, Hong Kong, and the United Kingdom, among other countries (Botzat et al. 2016, Soga and Gaston 2016). Most of this literature is restricted to experiences from the Global North, yet cities in the Global South are some of the fastest growing and are located in highly biodiverse areas (Pyle 2003). Whether the same patterns of loss of interest in nature by urban residents occur across the Global South has not been characterized in peer-reviewed literature but must be identified to provide pathways for peoples' participation in nature conservation and resource management (Castillo et al. 2006).

In this study, we asked: How do urban residents' knowledge, engagement, perception, and curiosity (KEPC) toward birds vary in four Peruvian cities and what factors may explain these variations? We chose birds as a study group because they are noticeable, hold aesthetic and cultural value, and can indicate environmental health (Ogden et al. 2014, Robinson 2019). Given the theory of extinction of experience, we hypothesized that bigger cities, particularly those in deserts, would have the lowest measures across all response variables. Within cities, we hypothesized that respondents who live in places with more greenspace and higher bird diversity would score higher on all response variables.

${ }^{1}$ Committee on Evolutionary Biology, University of Chicago, ${ }^{2}$ Facultad de Ciencias Biológicas, Universidad Nacional de la Amazonía Peruana, Iquitos, Peru, ${ }^{3}$ Facultad de Medicina Veterinaria, Universidad Peruana Cayetano Heredia, Lima, Peru, ${ }^{4}$ Laboratorio de Ecosalud y Ecología Urbana, Universidad Peruana Cayetano Heredia, Lima, Peru 
Fig. 1. Maps of study sites: (A) Lima (scale bar $10 \mathrm{~km}$ ); (B) Nauta (scale bar $1 \mathrm{~km}$ ); (C) Huacho (scale bar $2 \mathrm{~km}$ ); and (D) Iquitos (scale bar $5 \mathrm{~km}$ ). Maps constructed using R 4.0 in RStudio (R Core Team 2020, RStudio Team 2020) using the packages ggmap and ggsn (Kahle and Wickham 2013, Santos Baquero 2019).
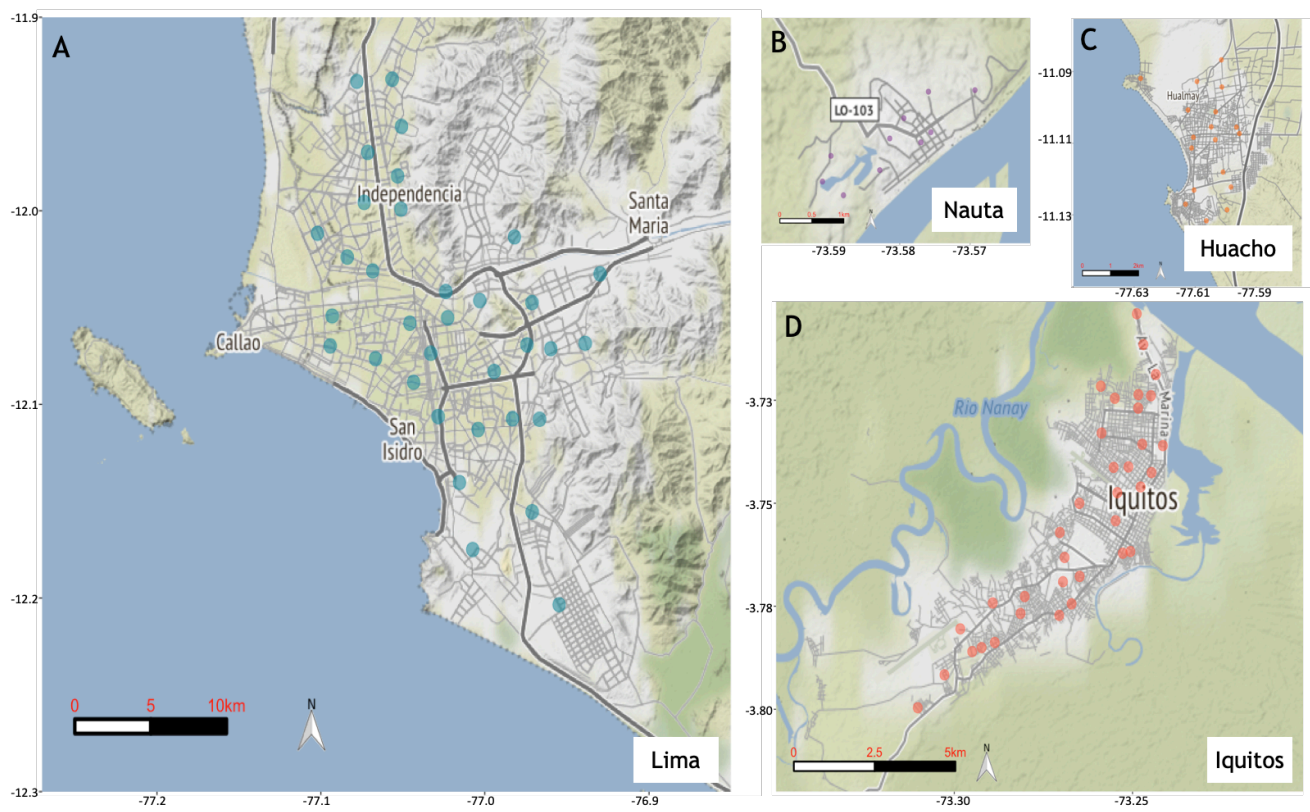

\section{METHODS}

To assess urban residents' KEPC and potential predictive factors, we collected environmental and bird diversity data at a site level, and socio-demographic data at an individual level.

\section{City and site selection}

We first chose the largest city (both in territory and population) in two Peruvian ecosystems (Lima in the Pacific Coastal Desert, and Iquitos in the Western Amazon), and then a smaller city about 3 hours away from each large city by highway (Huacho in the Pacific Coastal Desert, and Nauta in the Western Amazon; see Table 1 for general characteristics). This distance assured separation between cities, but proximity and inclusion in the same ecosystem. Difference in sizes gave another axis of comparison. Sites within cities were selected with the following criteria: $>200$ $\mathrm{m}$ from any other site, $<500 \mathrm{~m}$ above sea level, easily accessible by car, and, together, spanning the expanse of the city. Number of sites per city differed on account of the difference in size of cities. The distance between sites assured separation, whereas the inclusion within the same elevational range $(<500 \mathrm{~m}$ asl) assured that the bird communities were influenced by the city landscape rather than by different elevations (see Fig. 1 for city maps).

\section{Environmental and bird diversity data}

Following Piland (2020), we classified each site visually using satellite images acquired from Google Earth to characterize both a local (radius $=100 \mathrm{~m}$ around site coordinates) and a neighborhood measurement (radius $=500 \mathrm{~m}$ ) of greenspace and grayspace cover for each site (satellite images copyrighted to CNES/Airbus between 2016-2018, and accessed in 2019, Google Earth V.7.3.2.5776). Distance from nearest landmark (park, center of city, and water) edge to site coordinates was measured
Table 1. Study cities' characteristics. Population from citypopulation.de (in turn, from INEI 2017), except for Iquitos, for which we used the Maynas Province 2007 population estimate. This is because the estimate for the Iquitos metropolitan area (Brinkhoff 2020) is unofficial. Population growth calculated from the difference between the 2017 population estimate to the 2007 population estimate. Surface area for Lima and Huacho obtained from the Global Human Settlement Database (Florczyk et al. 2019). Surface area for Nauta and Iquitos calculated on Google Earth as described in Piland (2020). Density calculated by dividing population by surface area.

\begin{tabular}{|c|c|c|c|c|c|}
\hline City & $\begin{array}{l}\text { Environm- } \\
\text { ent }\end{array}$ & Population & $\begin{array}{r}\text { Pop. } \\
\text { Growth }\end{array}$ & $\begin{array}{r}\text { Surface } \\
\text { Area }\left(\mathrm{km}^{2}\right)\end{array}$ & $\begin{array}{r}\text { Density } \\
\left(\mathrm{ppl} . / \mathrm{km}^{2}\right) \\
\end{array}$ \\
\hline Lima & $\begin{array}{l}\text { Pacific } \\
\text { coastal } \\
\text { desert }\end{array}$ & $10,209,275$ & $16.91 \%$ & 876 & $11,654.42$ \\
\hline Huacho & $\begin{array}{l}\text { Pacific } \\
\text { coastal } \\
\text { desert }\end{array}$ & 141,395 & $2.55 \%$ & 31 & $4,561.13$ \\
\hline Iquitos & $\begin{array}{l}\text { Western } \\
\text { Amazon }\end{array}$ & 404,545 & $1.58 \%$ & 36.3 & $11,144.49$ \\
\hline Nauta & $\begin{array}{l}\text { Western } \\
\text { Amazon }\end{array}$ & 20,716 & $3.53 \%$ & 7.5 & $2,762.13$ \\
\hline
\end{tabular}

using the Google Earth distance tool on these same images. Satellite images processed were those available on Google Earth closest to bird point counts in 2017 and survey implementation in 2018. Bird point counts were conducted at every site coordinate in January-April 2017 as part of a related project (Grández et al., unpublished data). For this study, we used the following resulting 
diversity metrics: total species richness (number of species seen at each site), average number of individuals (number of individual birds seen at each site averaged across visits), and Simpson evenness (a measure of species equitability based on number of individuals at site, where 1 means that species all occur at the same frequency). There were 97 sites assessed for environmental and bird diversity data.

\section{Survey construction}

The knowledge, perception, and attitude (KPA) protocol, first developed for public and community health social diagnostics (Gumucio et al. 2011), was adapted to assess urban residents' perception, knowledge, and attitudes toward bird diversity in their neighborhood (inspired by Celis-Diez et al. 2017). Four classes of response variables were chosen (KEPC) in order to capture more than just knowledge under the Western science paradigm, in an attempt to measure multiple ways of connecting with nature (Dickinson 2013). Knowledge was approximated by the ability to identify illustrations of abundant birds in the city by common, scientific, or popular name, with popular names determined by the sample's most popular response (Appendix 1: Question 15 and Figs. A1.1-4; see also methods in Celis-Diez et al. 2017). Selection of birds to identify for each city was determined by the most abundant birds observed during the bird point counts (see above). Engagement with nature was assessed through ownership of pets and gardens (Appendix 1: Questions 9 and 10), following literature that suggests a higher appreciation of surrounding nature given a requirement to engage with non-human life outside (Bjerke et al. 2015). Perception of bird diversity was approximated by questions focused on a respondent's assessment of their neighborhood's bird community (Appendix 1: Questions 11-14). Curiosity was assessed by asking questions related to a respondent's interest in learning more about birds in their neighborhood (Appendix 1: Questions 16-17).

Surveys also included questions about a respondent's age, gender, level of education, employment, length of residence, their most recent previous residence (if applicable), time spent outside, and types of activities performed outside (Appendix 1: Questions 18). These variables, in conjunction with the environmental variables, were potential predictive factors of urban residents' attitude toward their surrounding nature. Once written, the survey was edited and commented on by three social scientists (Andrea Ugarte Villalobos, Department of Psychology, Pontificia Universidad Católica del Perú; Daniela Ugarte Villalobos, Department of Sociology, State University of New York-Albany; and Dr. Alaka Wali, Anthropologist at the Field Museum of Natural History), and approved by the University of Chicago Biological Sciences Division Institutional Review Board (Protocol \#IRB18-0045). See Appendix 1 for survey materials, including illustrated birds and consent language.

\section{Survey implementation}

Between January and April 2018, we implemented the human surveys at the bird point count sites (a total of 96 sites; one site did not have residential buildings) by going door-to-door or asking people on the street if they lived nearby. Survey respondents consisted of people who live at or near the bird observation site and spend time there during the day. This audience allowed us to relate the survey responses to the site's environmental information. A survey took an average of five minutes. There were six surveyors for all four cities, with NCP interviewing in all four cities, whereas the other five were split with three in Iquitos and Nauta (XV, EV, and Claudia Pezo), and two in Lima and Huacho (MC and CP). Ten people were surveyed at every site with three exceptions: one in Lima where we surveyed nine respondents, another in Lima where we surveyed 11 respondents, and one in Nauta where we surveyed 11 respondents. Surveys were carried out between 9:00 AM and 6:00 PM every day of the week. Surveyors were trained in the study's aim and objectives, as well as how to ask questions. Respondents were informed of the study's objective and asked if they consented to taking part. Questions not about birds were asked first (Appendix 1: Questions 1-10), whereas questions on birds (Appendix 1: Questions 10-17) were asked in the same order and last. If there was a lack of clarity in the question, the question was explained using words not on the survey. In some cases, interviewers wrote down their interpretation of a respondent's gender rather than asking how they self-identify, and as such, all discussion of gender from here on out will be presumed to represent interpretation of gender by surveyor, rather than true gender.

\section{Coding variables}

As many questions in the survey were open-ended, responses required coding for analysis. Employment (Appendix 1: Question 4) was coded using the North American Industry Classification System (United States 2017) where the response was categorized into an "industry" variable. Information about the respondent's last residency change (Appendix 1: Question 6) was coded based on where their last residence was in relation to their current residence ("movement"). Activities outside (Appendix 1: Question 7) were classed into the following: "recreation" (main objective: to pass time, enjoy the outdoors, or socialize), "exercise" (main objective: to promote physical health), "extractive" (main objective: to consume), "work" (main objective: to produce), and "other" (main objective: outside the prior categories or where the respondent did not elaborate). In cases where people listed more than one activity, both were counted. In the analysis, dummy variables were created for each answer. Respondents were asked to specify topics of interest in regards to birds (Appendix 1: Question 17) and these were categorized broadly by whether the topic was centered on the bird or the human, and whether it related to that focus directly, indirectly, aesthetically, recreationally, or intrinsically. These categorizations are inspired by the human valuation of nature paradigm where nature's value to human society is relative to direct harm or benefit (Direct), indirect ecosystem services (Indirect), aesthetic/cultural meaning (Aesthetic), recreational opportunities (Recreational), or existence (Intrinsic; Primack 2014).

\section{Data analysis}

All analyses were conducted in R 4.0 and RStudio, using the tidyverse $\mathrm{R}$ packages for data wrangling and visualization (Wickham et al. 2019, R Core Team 2020, RStudio Team 2020). Descriptive statistics (minimum, maximum, median, mean, and standard deviation for numeric variables or frequency in percentage for factor variables) were calculated for the full dataset and for each individual city using $\mathrm{R}$ package summarytools (Comtois 2020). 


\section{Exploratory analyses}

Principal component analysis (PCA) was used to explicitly summarize relationships between environmental and bird diversity variables in the full dataset and identify the dimension best characterizing the urban typology. The score on this dimension was used to describe each site (from here on, "greenspace score") in the models. Factor analysis of mixed data (FAMD) was used to summarize and visualize dimensions of attitudes on bird diversity by urban residents. Individuals were visualized on FAMD dimensions 1-4. All PCAs and FAMDs were run using the $\mathrm{R}$ package FactoMineR and visualized using factoextra (Lê 2008, Kassambara and Mundt 2020).

\section{Model construction}

Multivariate linear regression models were conducted using each FAMD dimension 1-4 score as a function of the following variables: age, gender, education, work, outdoor activities, weekly hours outside, residency length, last move, observed species richness, average number of individual birds, greenspace score, and Simpson evenness. Site was not included as a random factor, because the site variables (observed species richness, average number of individual birds, greenspace score, and Simpson evenness) deconstruct the site and are hypothesized to be potential factors in determining respondents' KEPC. Outlier respondents, i.e., those with unique categorical score, were excluded from the models. Three sites from Iquitos were excluded because their Simpson evenness bird scores were significantly higher than the rest: $0.1-0.4$, whereas the mean of the rest of the sites was 0.04 with a standard deviation of 0.01 . This pattern seems to be driven in two sites by the lack of Brotogeris spp. flocks, resulting in a more even species abundance distribution, and in the third site a low species diversity $(n=3)$ also resulting in a more even distribution of individuals. Full dataset models were run with and without the City variable as an independent variable. Models were also run on subsets of the dataset by city. All models used a 10fold cross-validation as the resampling technique, and stepwise selection. Best performing models within each run were chosen based on the lowest value of root-mean-square-error (RMSE). These analyses were conducted using the caret and leaps $\mathrm{R}$ packages (Kuhn 2020, Lumley 2020).

\section{RESULTS}

\section{Descriptive statistics}

Full descriptive statistics are included in Appendix 2. There were 961 respondents in the four cities of Iquitos $(n=350)$, Nauta ( $n$ $=101)$, Huacho $(\mathrm{n}=180)$, and Lima $(\mathrm{n}=330)$. Of these respondents, $52.8 \%$ were recorded as women, $46.1 \%$ were recorded as men, and $1.1 \%$ had no record of gender. The age distribution for all four cities was comparable (mean \pm sd for each city: Huacho $41.3 \pm 19.3$; Lima $43.3 \pm 19.4$; Iquitos $40.8 \pm 18.5$; and Nauta $41.4 \pm 16.1$ ), with a combined mean of 41.8 years old and standard deviation of 18.7 years. Respondents in Lima had more formal education than those in the other three cities, with $52 \%$ having completed university, whereas in the other three cities $15-18 \%$ completed university. Although half of respondents in each city worked in "other services" (mainly domestic labor) or were students, the occupation of the other half differed according to city size: Huacho's, Lima's, and Iquitos' respondents worked mainly in retail $(9.4 \%, 10.3 \%, 17.7 \%$, respectively), were retired $(7.8 \%, 8.7 \%, 2.9 \%)$, or worked freelance (Huacho and Iquitos;
$6.7 \%$ and $10.6 \%$, respectively) or in administration and support (Lima, 6.6\%). In Nauta, the workforce of respondents was further made up of educators $(15.8 \%)$ and those who worked in agriculture, forestry, fishing, and hunting (14.9\%). Lima's respondents work more frequently in market-based jobs (retail and administration and support) than those in the other three cities. Nauta's respondent workforce reflects the local economy, which revolves around agriculture, hunting, and fishing, and the fact that the city has schools from primary to post-secondary levels, with a higher proportion of educators and people who work directly with natural resources (Ministerio de Transportes y Comunicaciones 2008).

These differences between cities are also reflected in the nature of the activities done outside. Although in Huacho, Lima, and Iquitos respondents rarely worked outside $(7.8 \%, 3.3 \%, 7.4 \%$ respectively), $14.9 \%$ of Nauta respondents reported working outside. Nauta also seems to be a more transient city with respondents' average residency length being 15.1 years, whereas in the other cities average residency length for respondents was between 18 and 20 years. The most common movement respondents in Nauta experienced was moving from rural to urban areas $(35.6 \%)$, whereas in the other three cities it was within the same city (35\% in Huacho, $37 \%$ in Lima, and $52.9 \%$ in Iquitos). Mobility within Nauta for respondents was relatively low $(26.7 \%$ in city and $2 \%$ in the same neighborhood) and this may reflect the relatively recent growth given that it positions itself as an important port and connector to Iquitos from the rest of the country (Ministerio de Transportes y Comunicaciones 2008, Figallo and Vergara 2014; Table 1). Lima is the only study city whose respondents reported international moves $(2.4 \%)$.

Respondents from the Amazonian cities, Iquitos and Nauta, gave more responses for the bird identification exercise, and on average identified more illustrations correctly than those of the coastal desert cities (Fig. 2b-d). These cities also had more respondents with gardens and had a higher average number of reported species in their garden than those of the desert cities (Fig. 3c-d). Both large cities, Lima and Iquitos, had a higher fraction of pet owners than their smaller counterparts (Fig. 3b). Despite these differences, over $90 \%$ of respondents had noticed birds in their neighborhoods (Fig. 4b). Over half of respondents $(64.1 \%$, with individual cities ranging from $53.2 \%$ to $73.6 \%$ ) believed the bird diversity in their neighborhoods to be low and, on average, estimated that about four different types of birds occurred in their neighborhood (species richness based on bird surveys varied from three to 35 in 87 sites, averaging at about 17 species/site; Fig. $4 \mathrm{c}-$ d). Over $70 \%$ of total respondents in each of the four cities wanted to know more about birds (Fig. 5b). The most popular category of subject matter people wanted to know about birds was "birds intrinsic," a category consisting of information about the birds themselves, e.g., identification, habitats, behavior, migration, and evolution.

\section{Exploratory analyses}

The full environmental PCA to identify an appropriate dimension to characterize greenspace and grayspace was performed on 97 sites using the following log-transformed traits: percent land cover, at both local and neighborhood scales, of trees, buildings, grass, asphalt, and dirt; distance to nearest landmarks of park, water, and center of city; average number of individual birds; 
Fig. 2. Results for "knowledge" response variables: (a) Boxplots for factor analysis of mixed data (FAMD) Dimension 1 score by city; (b) Number of birds responded on bird identification survey by city; (c) Birds identified correctly when graded according to either an "accepted" common name or a scientific name; (d) Birds identified correctly when graded according to the most popular name given; and (e) Best performing models for each dataset (Huacho, Iquitos, Lima, Nauta, and the full combined dataset) with variable coefficients and quality measurements (root-mean-square-error [RMSE], $\mathrm{R}^{2}$, and Bayesian information criterion [BIC]).

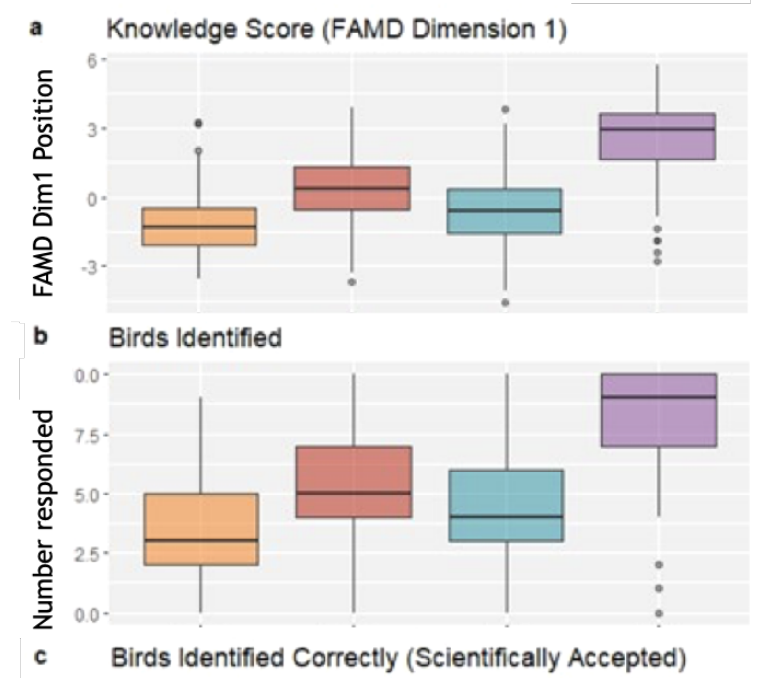

e Best Multivariate Models for Each Dataset (Response = Knowledge Score)

\begin{tabular}{lll}
\hline City & Variable Coefficients & Quality Measures \\
\hline Huacho & 0.96 (Work: Admin \& Support) & RMSE = 1.2224 \\
& 0.25 (Gender: Masculine) & $R^{2}=0.1267$ \\
& 0.17 (Work: Arts \& Entertain.) & $\mathrm{BIC}=-13.4238$ \\
& 0.16 (Work: Education) & \\
& 0.02 (Age) & \\
& -0.21 (Work: Agriculture) & \\
& 1.73 (Work: Agriculture) & RMSE $=1.3655$ \\
& 1.64 (Work: Education) & $R^{2}=0.1195$ \\
& 1.26 (Work: Science \& Tech) & BIC $=-23.3147$ \\
& 1.23 (Work: Arts \& Entertain.) & \\
& 0.97 (Work: Freelance) & \\
& 0.74 (Unemployed) & \\
& 0.65 (Work: Retail) & \\
& 0.38 (Work: Other) & \\
& 0.38 (Moved w/in City) & \\
& 0.35 (Regular\# Hrs. Outside) & \\
& 0.30 (Exercise Outside) & \\
& 0.02 (Species Richness) & \\
& -0.01 (Years in Residency) & \\
& -0.14 (Level of Education) & \\
& -0.51 (Work Outside) &
\end{tabular}
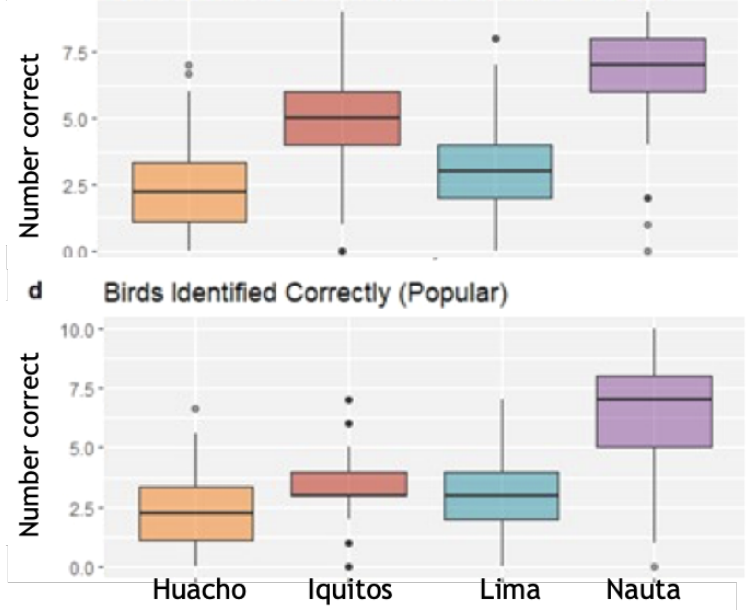

$\begin{array}{lll}\text { Lima } & 0.11 \text { (Work: Admin \& Support) } & \text { RMSE }=1.3879 \\ 0.10 \text { (Gender. Masculine) } & R^{2}=0.0487 \\ 0.00 \text { (Age) } & \mathrm{BIC}=5.0238 \\ & 0.00 \text { (Level of Education) } & \\ & & \\ & 0.49 \text { (Level of Education) } & \text { RMSE }=1.5024 \\ \text { Nauta } & 0.04 \text { (Age) } & R^{2}=0.3124 \\ & 0.03 \text { (Years in Residency) } & \mathrm{BIC}=-12.0405\end{array}$

$\begin{array}{lll}\text { Full } & \text { RMSE }=1.3676 \\ & 1.29 \text { (City: Nauta) } & R^{2}=0.4167 \\ 1.18 \text { (Work: Education) } & \mathrm{BIC}=-439.9493 \\ 0.62 \text { (Work: Freelance) } & \\ 0.43 \text { (City: Lima) } & \\ 0.29 \text { (Regular \# Hrs Outside) } & \\ 0.02 \text { (Species Richness) } & \\ 0.01 \text { (Age) } & \\ \end{array}$

Simpson evenness; and species richness. Percent land cover at both scales of water and wetlands were excluded because they did not show normal distributions. Dimension 1 (PC1; "greenspace score") demonstrated an urban gradient, where higher numbers were associated with greenspace and trees and lower numbers with buildings and asphalt. Cities showed a progression along the urban gradient with sites in Huacho and Lima tending toward negative $\mathrm{PC} 1$ values and more urban characteristics (for example, higher $\%$ of building cover), Iquitos sites spread out on the middle of the axis, and Nauta tending toward positive PC1 values and more tree-heavy or grass-heavy sites. Observed species richness is most strongly associated with dimension 1 (less urban, more birds). Simpson evenness is also associated with dimension 1 (less urban, less evenness). The average number of individual birds at a site was positively associated with dimensions 1 and 2 (less urban, more birds). Interpretation of other dimensions and PCA loadings are included in Appendix 3.
The FAMD for all respondents resulted in a first dimension that summarized "knowledge" variables (explaining 23.98\% of variance), a second dimension that summarized "curiosity" $(12.82 \%)$, a third dimension that summarized "engagement" (11.31\%), and a fourth dimension that summarized "perception" (10.24\%; Table 2). Individual respondents' survey responses were mapped onto these four dimensions with $95 \%$ confidence ellipses to assess visually whether any of the independent variables (human or environmental) display clustering. The only variable that displayed strong clustering was city membership (see Figs. 2-5 for differences in score distribution by city). Categories describing a respondent's interest were excluded from this analysis because the large number of potential answers overwhelmed the construction of dimensions. Outlier surveys (surveys whose contribution to the construction of dimensions singularly defined it) were excluded and the FAMD was re-run. The final FAMD included 956 surveys. 
Table 2. Final factor analysis of mixed data (FAMD) loadings (rounded to two decimal places) for each survey response variable. In parentheses, the percent of variance explained by the respective dimension.

\begin{tabular}{|c|c|c|c|c|}
\hline Survey Response Variable & $\begin{array}{c}\text { Dim. } 1 \\
(23.98 \%)\end{array}$ & $\begin{array}{c}\text { Dim. } 2 \\
(12.82 \%)\end{array}$ & $\begin{array}{c}\text { Dim. } 3 \\
(11.31 \%)\end{array}$ & $\begin{array}{c}\text { Dim. } 4 \\
(10.24 \%)\end{array}$ \\
\hline \# of Responses (ID) & 0.44 & 0.03 & 0.05 & 0.00 \\
\hline Score on ID (Taxonomic) & 0.47 & 0.03 & 0.05 & 0.00 \\
\hline Score on ID (Popular) & 0.42 & 0.03 & 0.06 & 0.00 \\
\hline Number of categories & 0.03 & 0.48 & 0.01 & 0.10 \\
\hline Interested in more info & 0.03 & 0.44 & 0.03 & 0.11 \\
\hline Species in garden & 0.19 & 0.00 & 0.34 & 0.00 \\
\hline Pet ownership & 0.02 & 0.05 & 0.18 & 0.00 \\
\hline Garden ownership & 0.12 & 0.00 & 0.44 & 0.00 \\
\hline Subjective level of biodiversity & 0.01 & 0.10 & 0.01 & 0.33 \\
\hline Estimated bird species & 0.03 & 0.06 & 0.00 & 0.17 \\
\hline Perception of birds & 0.00 & 0.06 & 0.03 & 0.39 \\
\hline
\end{tabular}

\section{Best-performing models}

The best performing multivariate linear models were constructed using a dataset that excluded outlier individuals (total respondents included in models $=911 ; 320$ in Iquitos, 101 in Nauta, 317 in Lima, and 173 in Huacho; compared to the 961 total respondents). For each set of models constructed for each response variable, the model with the lowest RMSE was selected for interpretation. Of these, the model with the lowest Bayesian information criterion (BIC) score (-439.94) was the full model, including the city variable, with the response variable as the first FAMD dimension ("knowledge"; see Fig. 2e), and the model with the lowest RMSE was the model for Iquitos where the response variable is the fourth FAMD dimension ("perception"; see Fig. $4 \mathrm{e})$. RMSE variation was low amongst all models presented, and $\mathrm{R}^{2}$ values never surpassed 0.42 , with the majority remaining below 0.15 (Figs. 2-5).

The best models for the response variable "knowledge" were quite different among cities (Fig. 2e). In Iquitos, a variety of work types most strongly affected the "knowledge" score (coefficients between 1 and 2), whereas working outside and a higher level of education were strong negative factors. Level of education in Lima also had a negative coefficient, although so small that it is likely not seriously affecting respondents' knowledge, whereas in Huacho and in Nauta, working in education was a strong indicator of knowledge about birds. In Huacho, working in agriculture had a negative influence on knowledge of birds. The strongest model for the knowledge dimension was the full dataset, including the city variable. In this model, residency in Nauta or in Iquitos alone was the best predictor of bird knowledge.

When assessing models with the response variable "curiosity" score, the strongest negative coefficients are found in work types that require time inside: e.g., in the Huacho model, working in manufacturing, or in the Iquitos model, working in administration and support, both with coefficients less than -1.0. The full dataset model is the strongest model if judged by BIC $(\mathrm{BIC}=-82.05)$ and no time spent outside has the strongest negative coefficient (-0.49). However, the distributions of scores and variables show that there are few strong differences in response variables across cities (Fig. 5a-c).

Factors predicting score of engagement, as measured by ownership of pets and gardens, and garden species richness, differed among cities (Fig. 3e). In Huacho and Lima, the most interpretable factor is the environmental dimension score: places with a higher "greenspace score", and thus more greenspace/trees, are more likely to have residents with pets and gardens. In Iquitos' best performing model, Simpson evenness had the largest coefficient. This coefficient was strongly negatively associated with the engagement score and may also be a stand-in for a greenspace score, where a higher Simpson evenness score suggests less species richness and a higher amount of grayspace. In Nauta, being a student made a respondent more likely to have a pet or a garden, although we do not know who in the family chose to have a pet or garden.

Finally, the best performing multivariate models for the fourth FAMD dimension score, "perception", at most explain $9.4 \%$ of the variance (see $\mathrm{R}^{2}$ of the Lima model; Fig. 4e). The strongest coefficient was from Nauta where people working in the science and technology sector had a positive association (2.58). The strongest negative association was residency in Nauta in the full dataset. There were no common factors found between the five models.

\section{DISCUSSION}

"Extinction of experience" leads us to believe that residents of big cities, regardless of where they are, have fewer opportunities to interact with nature, and thus have lower scores across measures of knowledge, engagement, perception, and curiosity (KEPC) toward nature. However, we show that urban residents' KEPC may depend more on the socio-environmental context of the city they reside in than on the size of it. Survey respondents in the Pacific coastal desert have lower "knowledge" scores than those in the western Amazon, yet the best models in each city differed. Likewise, respondents in the desert have lower "engagement" scores than those in the Amazon, but the scores for respondents in the desert seem tied to availability of greenspace. "Perception" scores are low across all four cities, although the Amazonian cities have lower scores, and "curiosity" scores are high across all four cities. Together, these results suggest a potential urban humannature connection, grounded in the city in which people live.

Urban residents in the western Amazon "know" more about birds Formal education has been thought to predict scientific and natural history literacy (Luck et al. 2009, Celis-Diez et al. 2017), yet urban residents from the Pacific coastal desert consistently 
Fig. 3. Results for "engagement" variables: (a) Boxplots for factor analysis of mixed data (FAMD) Dimension 3 score by city; (b) Proportion of residents who were pet owners by city; (c) Proportion of residents who were garden owners by city; (d) Number of species reported in their gardens by city; and (e) Best performing models for each dataset (Huacho, Iquitos, Lima, Nauta, and the full combined dataset) with variable coefficients and quality measurements (root-mean-square-error [RMSE], $\mathrm{R}^{2}$, and Bayesian information criterion [BIC]).

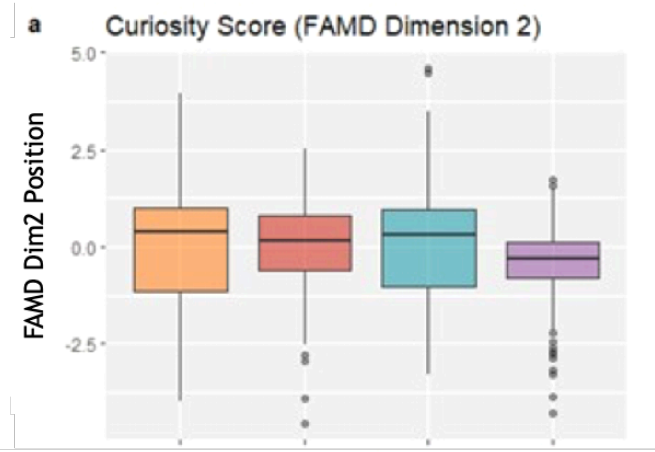

b Respondent Curiosity

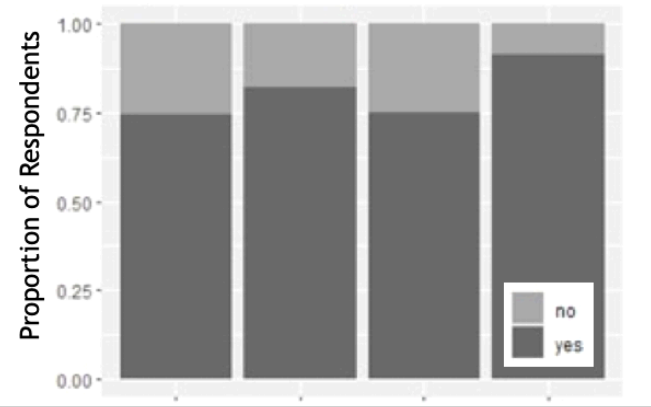

c Respondents' Category Quantity

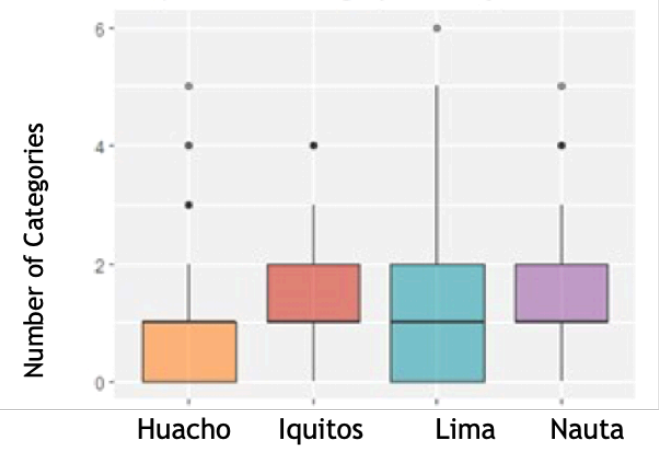

e Best Multivariate Models for Each Dataset (Response = Curiosity Score)

\begin{tabular}{lll}
\hline City & Variable Coefficients & Quality Measures \\
\hline Huacho & 0.26 (Level of Education) & RMSE $=1.2353$ \\
& -0.03 (Age) & $R^{2}=0.2266$ \\
& -0.81 (Work: Retired) & $\mathrm{BIC}=27.8812$ \\
& -1.71 (Work: Manufacturing) & \\
& & \\
& & \\
Iquitos & 0.50 (Exercise Outside) & RMSE $=1.153$ \\
& 0.20 (Level of Education) & $R^{2}=0.1302$ \\
& -0.01 (Age) & BIC $=-26.1836$ \\
& -1.01 (Work: Admin \& Support) &
\end{tabular}

\begin{tabular}{lll}
\hline Lima & 0.67 (Student) & RMSE $=1.3202$ \\
& & $R^{2}=0.0601$ \\
& BIC $=-0.1525$ \\
& \\
& \\
& \\
& \\
& \\
Nauta & 0.03 (Age) & RMSE $=1.0214$ \\
& & $R^{2}=0.1421$ \\
& BIC $=-4.3257$
\end{tabular}

RMSE $=1.217$ $R^{2}=0.121$ $\mathrm{BIC}=-82.0451$ scored lower along the "knowledge" axis and variables than urban residents from the western Amazon despite having more formal education (Fig. 2), suggesting that formal education, at least in the Pacific coastal desert, does not influence whether urban residents can identify local birds. The best model for the full dataset identified residence in Nauta or Iquitos as the strongest predictive factor for high "knowledge" score (Fig. 2e). Residents from these cities also consistently scored higher in the bird identification exercise, despite having less formal education than those of the desert cities. This points to a stronger extracurricular environmental awareness. The regional economy for Nauta and Iquitos, as with the rest of the Amazon, revolves around its natural resources, with birds providing an attractant for tourism, for which Iquitos and Nauta are points of access (Figallo and Vergara 2014). By contrast, in the region of Lima, the cities Huacho and Lima are industrial and commercial centers (Lazarte 2015). Results from these cities show similar knowledge results to those found in Santiago, Chile, another capital city in a similar, albeit higher elevation, ecosystem (Celis-Diez et al. 2017, where most respondents identified two to three birds correctly out of 10).

\section{Urban residents' ownership of gardens and pets is constrained by} environment

"Engagement" scores for the Pacific coastal desert cities suggest that socioeconomic factors are more important for determining these scores than in the Amazonian cities, where residents had 
Fig. 4. Results for "perception" variables: (a) Boxplots for factor analysis of mixed data (FAMD) Dimension 4 score by city; (b) Proportion of residents who had seen birds in their neighborhood; (c) Proportion of residents who perceived categories from lowhigh of biodiversity; (d) Number of species estimated in their neighborhoods; (e) Best performing models for each dataset (Huacho, Iquitos, Lima, Nauta, and the full combined dataset) with variable coefficients and quality measurements (root-mean-square-error [RMSE], $\mathrm{R}^{2}$, and Bayesian information criterion [BIC]).

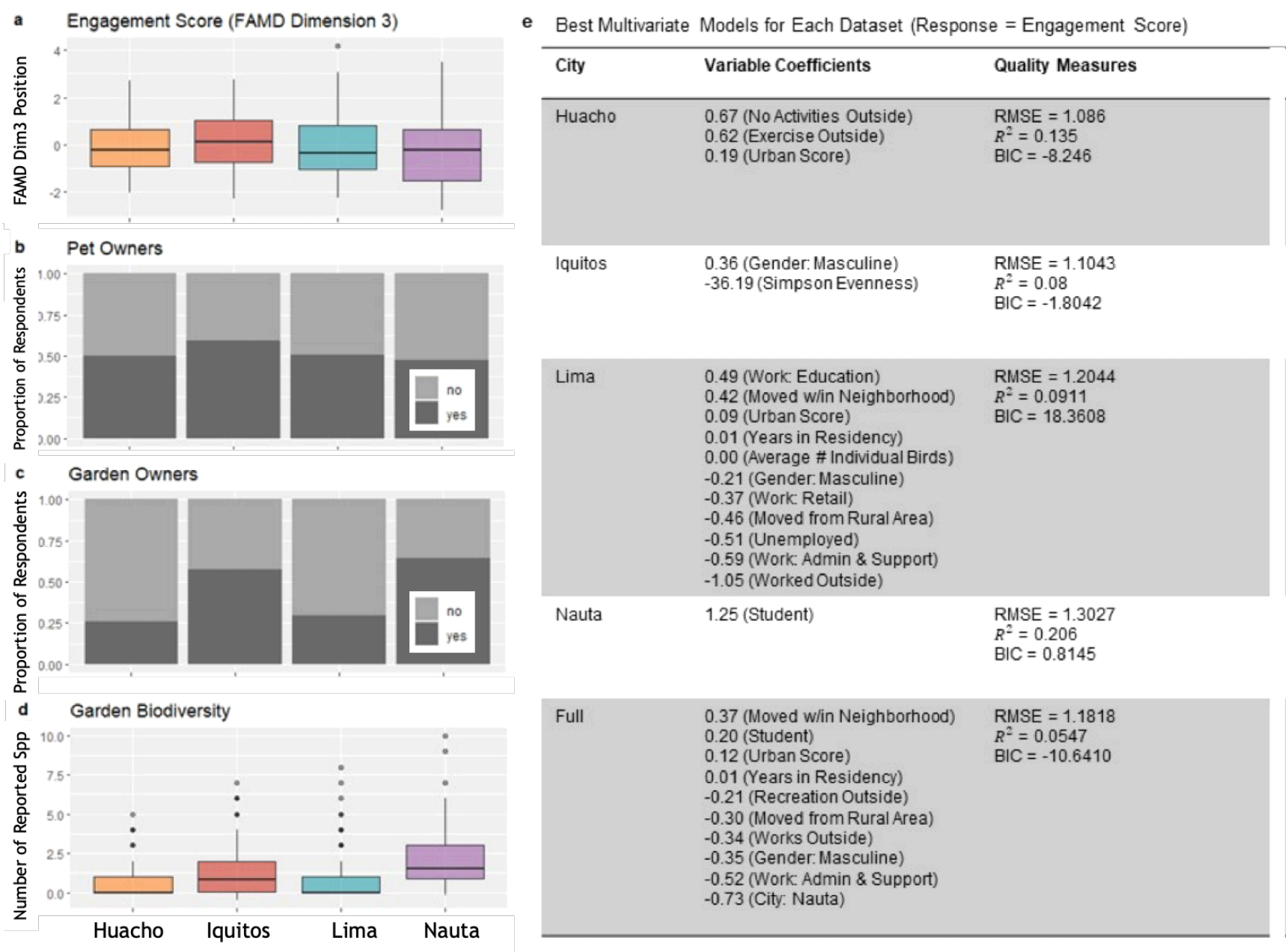

more gardens with more garden species more consistently (Fig. $3 \mathrm{c}-\mathrm{d})$. The overall model identified a high greenspace score as a positive factor in determining engagement score, yet the cityspecific models differed in the role of the environment versus demographic factors (Fig. 3e). In Lima, the best model identified unemployment and moving from a rural area as negative factors - two factors that are indicative of low socioeconomic class in the capital. From a resources perspective, this makes sense: water access constrains the ability to have a garden, and water access (as well as more greenspace) is linked to higher socioeconomic levels (Ioris 2012, Bell 2015, Alata Ninapaytán et al. 2019). Water access for plants may not be as linked to higher socioeconomic levels in the Amazon where high levels of rain and the surrounding wetlands make water for gardens easily accessible. This is supported by the fact that non-environmental coefficients in the models for Iquitos and Nauta are low (Fig. 3e). Simpson evenness, however, had a very high coefficient in Iquitos and could function as a potential proxy for how urban a site is given that a higher Simpson evenness score suggests a lower species richness and a higher amount of grayspace, and thus less space or water for a garden or a pet.

However, these measures of quantifying "engagement" should be viewed with caution because the assumptions of what they measure come from another part of the world. What it means to have a garden or a pet is defined culturally and may vary from place to place. For example, some respondents said they did not have a pet, but then later mentioned feeding stray animals. Our questionnaire also used the word "jardin", connoting a flower garden, rather than "huerta", which suggests a vegetable or fruit garden. We quickly incorporated "huerta" into the conversation we had with respondents while implementing the survey; however, this may suggest that these percentages are underestimates of garden ownership in our study cities. Additionally, the concept of 
Fig. 5. Results for "curiosity" response variables: (a) Boxplots for factor analysis of mixed data (FAMD) Dimension 2 score by city; (b) Proportion of residents interested in learning more about birds; (c) Number of categories respondents' answers on what they'd like to learn about birds fell into; and (e) Best performing models for each dataset (Huacho, Iquitos, Lima, Nauta, and the full combined dataset) with variable coefficients and quality measurements (root-mean-square-error [RMSE], $\mathrm{R}^{2}$, and Bayesian information criterion [BIC]). (d) was skipped for ease of comparison across figures.

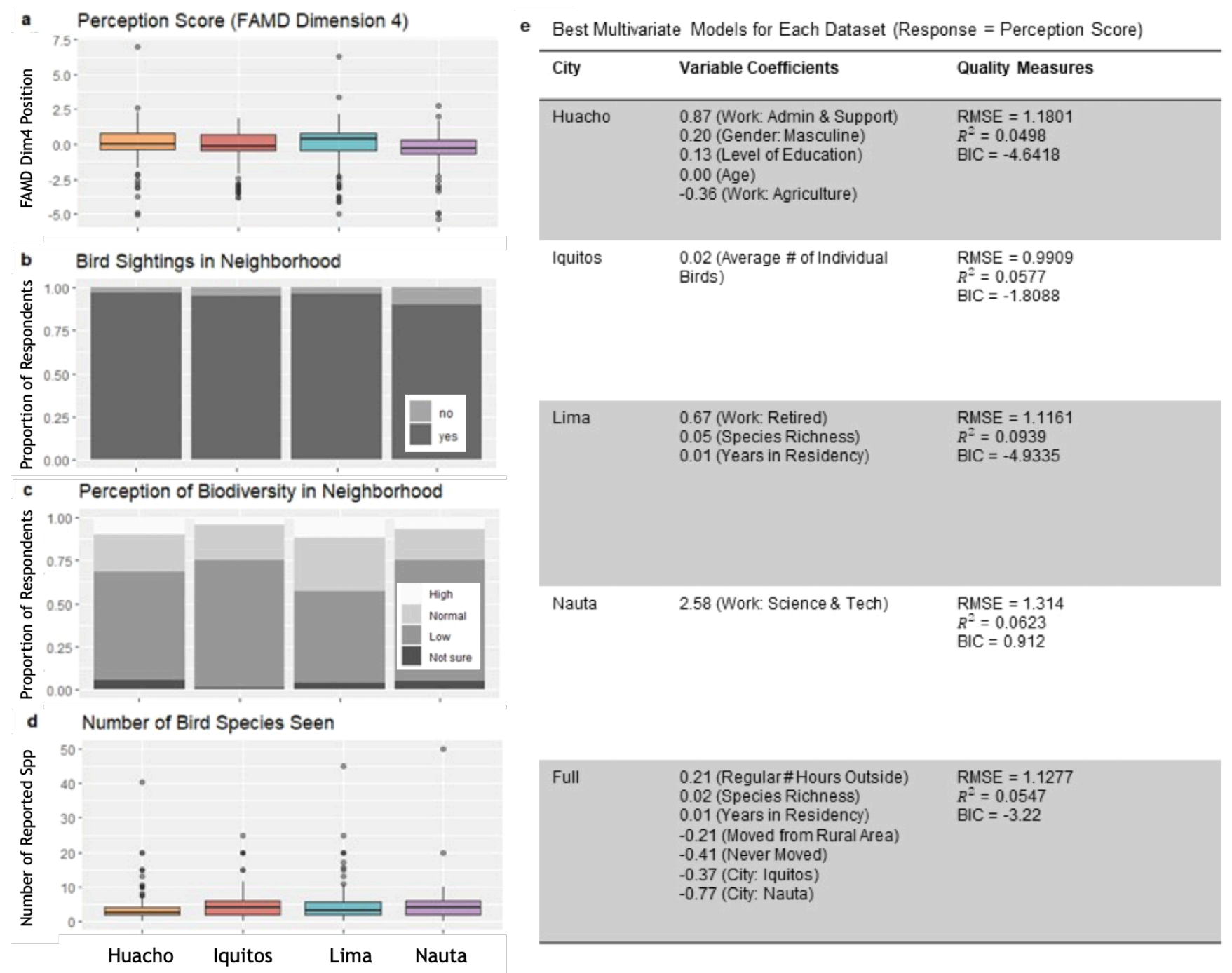

having a home garden may be inapplicable to a context in which urban residents still tend to rural fields (chacras; Hecht et al. 2021), as may be the case in at least three of the four cities (Huacho, Iquitos, and Nauta). Anecdotally, there were some respondents, especially in Nauta, who would say they did not have gardens, but then told us about their chacras. This result highlights the need for more place-specific literature on this topic.

Despite these limitations, respondents in our Amazonian cities had much higher percentages of gardens (Iquitos $57.7 \%$ and Nauta $64.4 \%$ ) than those in reported global North cities such as Stockholm, Sweden (16\%), and Dunedin, New Zealand (19$27 \%$ ), which were more similar to the percentages of reported garden ownership in Lima (29.5\%) and Huacho (26.4\%; Cox and Gaston 2018). Neither Dunedin nor Stockholm are in deserts, suggesting that although water access and environment may play a part in these differences, so does culture and socio-geographic position. Culture and socio-geographic position also influence how we interpret our results. For example, having property in both rural and urban areas can be a mark of a higher socioeconomic class in the global North, requiring enough wealth to purchase and manage two properties (Mendham and Curtis 2010, Stiman 2020). This is not necessarily the case in the global South, where there are still prevalent concepts of community ownership and family connectivity along the rural-urban gradient, land ownership can be acquired through settlement rather than purchase (including in urban areas), and property taxes are not high or enforced (Browder and Godfrey 1997, Padoch et al. 2014, Diep et al. 2019). Therefore, ownership of gardens or pets and 
whether it relates to engagement with nature depends on the city and where in that city you live.

\section{Urban residents' perception of bird diversity in their city may also depend on ecosystem}

Residents in all four cities perceived their neighborhood's bird diversity as low, yet the proportion of residents per city with this answer is higher in the Amazon than in the Pacific coastal desert (Fig. 4b-c), suggesting that how urban residents perceive their neighborhoods' bird diversity is a function of context. Cities are generally less biodiverse than their surroundings and cities' bird diversity measures are more similar to each other than to their surroundings (McKinley 2006, Aronson et al. 2014, Sol et al. 2020), but this does not mean that cities are completely devoid of bird diversity or that they are always less speciose than their surroundings (Piland 2020). In some cities, the input of energy and resources by humans supports more individual birds (Marzluff 2001), and this seems to be the case in Lima, where the average number of individual birds per site (41.07 \pm 29.1$)$ was higher than Huacho $(35.72 \pm 17.5)$ or Iquitos $(34.5 \pm 11.7)$. In Nauta, the average number of individual birds per site is 50.04 \pm 23.8 and may still be relying on a mixture of urban and rural resources (a situation hypothesized with theoretical models; Anderies et al. 2007).

In the Amazon, cities' surroundings are some of the most bird speciose in the world; in comparison, the cities themselves are species-poor. In the Pacific coastal desert, the surroundings, although still speciose, harbor birds that live in patches or are harder to see. Thus, in comparison, the cities have a similar number of bird species and sometimes more (Piland 2020). In our study, we registered a range of three species in one site in Iquitos to 35 species in another site in Iquitos, and a mean species richness ranging from 11.5 species/site (Huacho) to 23.9 species/site (Nauta). When asked to quantify, residents on average said there were about four different species of birds regardless of how urban the site was or how many species were observed during point counts (Fig. 6). Yet, a higher proportion of people in Nauta and Iquitos categorized their neighborhood as having "low" bird diversity (Fig. 4c).

Fig. 6. Localities and their average number of species observed by point counts (orange) and average number of species estimated by residents (purple), organized by greenspace score.

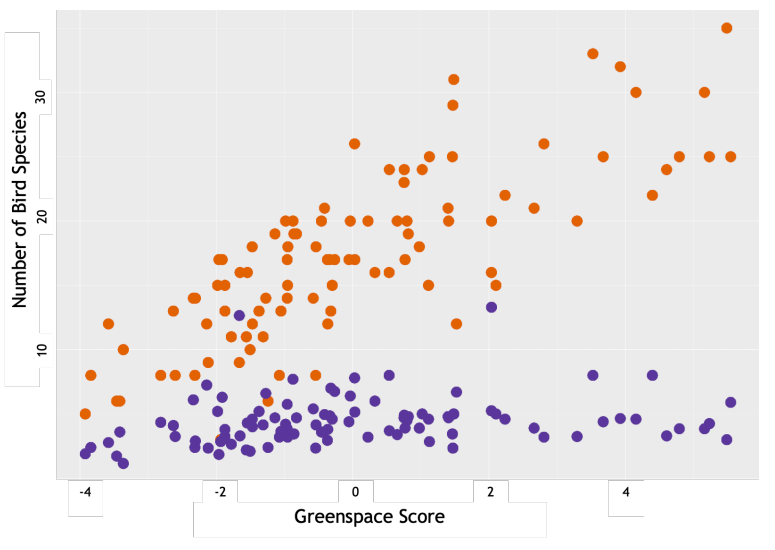

Urban residents across the board want to know more about birds In all four cities, over $75 \%$ wanted to know more about the birds in their neighborhoods (Fig. 5b). From the group of residents that were interested in learning more about the birds in their neighborhoods, the majority of respondents were interested in information about birds themselves. The second most popular general category of response differed by region: those of the coastal desert were most interested in information about how birds relate to humans directly, e.g., how to keep them as pets or raise them, whether they transmit diseases, etc. (about $16 \%$ for both cities), whereas in the lowland rainforest, respondents were interested in information about what supports or interacts with the birds, in particular, their habitat, their ecological relationships, etc. $(\sim 17 \%$ in Iquitos and $\sim 13 \%$ in Nauta). After these three categories, the most popular category for all four cities was information for information's sake. Many respondents said they would be interested in learning more simply because it is always good to know more. This suggests that although urban areas may diminish the opportunity to spend time in places considered to be "natural", it does not diminish "orientation", that is, the ability to perceive, be interested in, and be motivated to interact with natural elements (in these cities, with birds). This aspect has been shown to be more important than "opportunity" in other cities (such as in Brisbane, Australia; Lin et al. 2014), and has been theorized to be another casualty of urbanization as a driver of "extinction of experience" (Soga and Akasaka 2019).

Many studies, when they ask about "orientation," "knowledge," or "connection," focus on specific types of these that may not be appropriate for all populations (Dickinson 2013). Connectedness to and willingness to act in the interest of nature have been measured in different ways: the Connectedness to Nature Scale (e.g., Mayer and Frantz 2004, Olivos et al. 2011); visits, hiking, and backpacking in parks (e.g., Zaradic et al. 2009, Wright and Matthews 2015); and knowledge of Linnaean classifications of wildlife (e.g., Cotterill 1995, Celis-Diez et al. 2017). Yet, the Connectedness to Nature Scale has been shown to be biased and ineffective (Perrin and Benassi 2009, Zhang et al. 2014). Asking about visits to protected parks in the United States prioritizes the experiences of those that established the protected parks or those like them, often those who are in more racially or economically privileged classes (Byrne and Wolch 2009, Wolch et al. 2014, O'Brien 2015, Mock 2017). Knowledge of Linnean classifications assesses only one type of identification of wildlife that has a history of being inaccessible to those outside groups of power, and glorifies an individual whose original classifications included racist characterizations of humans (Boster et al. 1986, Spickard et al. 1995, Dickinson 2013). In this study, we show a multipronged approach to assessing human-nature connection, and recommend in further studies the use of methodologies where participants have more control over how connections are characterized, for example, photovoice methodologies (Wang and Burris, 1997).

The possibility of an urban human-nature connection

Respondents in all four of our study cities perceived and were interested in birds across neighborhoods, with different socioeconomic, cultural, and racial histories (Figs. 4 and 5). The fact that urban residents are most interested in information about the birds themselves rather than how to capitalize on them shows that there are other non-monetary benefits that nature may 
provide for urban residents (for more information on potential benefits, see Masterson et al. 2019). Supporting these already existing orientations, while attempting to act more as a translator between different economies and politics rather than as a "change agent", can empower community participation in politics, selfdetermination, and, ultimately, environmental management and stewardship (Wali et al. 2017).

Additionally, our research runs counter to literature that prescribes a focus on children as a long-term investment to prevent the extinction of experience (Miller 2005), because children have the strongest possibilities in creating a connection to nature (Chawla 1999). During survey implementation, many survey respondents of all ages went on to engage in a conversation to suggest ideas on how to engage residents in noticing and learning about neighborhood birds. One respondent from Lima was very excited to think about ways to involve their child: they mentioned puppet shows about birds at the park, interactive activities at the park, and creating local field guides. Adult respondents in all four cities shared many thoughts and questions on birds that were hard to categorize within this context. Some of these questions included: "Why do we not have the lions and tigers that we see on TV? Why are the birds that we see here not on TV?"; "Do the birds sing because they're sad?". The focus on children is important, but children do not exist in a vacuum; they interact with adults who themselves can communicate their connection to nature (Schuttler et al. 2018). Harnessing the excitement of the parents and other adults is beneficial, not just in engaging in a larger conversation and answering questions together, but also for society. Limiting our scope to generational change artificially transfers responsibility to the next generation when we can start creating a more environmentally and socially just society now (Carruthers 2018).

\section{CONCLUSION}

The environmental movement's romanticization of wildness and pristine landscapes has painted nature as inaccessible for many urban residents and fomented the idea of extinction of experience in urban areas (Cronon 1995, Pyle 2003). Yet, these ideas of "wildness" and "pristine" are not well supported by experience or evidence. For example, most natural areas, such as the contiguous forests of the Amazon, are the settings in which humans have evolved and continue to evolve, and they have been formed by this relationship (Heckenberger et al. 2014). In The Nature of Cities, Marianne Krasny (Cornell University) writes of her surprise at the strength of the connection to nature she felt in the Lower East Side of Manhattan (Krasny 2015). Instead of feeling this connection from the sight of a pristine alpine landscape, or a wild oceanic wave, she feels it from meeting a family working a community garden. She continues to reflect that, in preventing "extinction of experience", it is necessary to define what the experience you're preserving is. We expected to see patterns of loss of KEPC and thus a growing indifference as cities and neighborhoods become more urban. However, although knowledge and engagement (garden and pet ownership) did generally decrease from smallest city to largest city, the complexity and diversity of the best performing models suggest interactions between cities' natural and social histories. Perception and curiosity measurements remained broadly constant across cities, underlining that the urban environment itself may not be a definitive factor in people's disconnection to nature. Respondents in these urban communities are noticing and are interested in nature, and could thus lead their communities toward sustainability. As conservation professionals, our role could lie in connecting residents to those who may support their initiatives financially, politically, or technologically, and, as residents, our role could lie in engaging with our own communities.

Responses to this article can be read online at: https://www.ecologyandsociety.org/issues/responses. php/13043

\section{Author Contributions:}

NCP took part in study design, data collection, data processing, data analysis, writing, and editing. EV took part in data collection, data processing, and editing. All other authors took part in data collection and editing.

\section{Acknowledgments:}

We would like to acknowledge and thank the municipalities of all four cities where we worked, as well as the respondents themselves for participating in the project. Additionally, we'd like to thank Dr. John Bates, Dr. Alaka Wali, Dr. Trevor Price, and Dr. Benjamin Blanchard, as well as anonymous reviewers, for comments on various forms of this manuscript, and Andrea and Daniela Ugarte Villalobos for their comments on the survey design. This material is based upon work supported by the National Science Foundation Graduate Research Fellowship Program under Grant Nos. DGE-1144082 and DGE-1746045. Any opinions, findings, and conclusions or recommendations expressed in this material are those of the authors and do not necessarily reflect the views of the National Science Foundation. We dedicate this work to Claudia Pezo.

\section{Data Availability:}

Datalcode available on request because of privacylethical restrictions The datalcode that support the findings of this study are available on request from the corresponding author, NCP. None of the datalcode are publicly available because the data are georeferenced to individuals' residency and could compromise the privacy of research participants. Ethical approval for this research study was granted by the University of Chicago Biological Sciences Division Institutional Review Board (Protocol \#IRB18-0045).

\section{LITERATURE CITED}

Addanki, S. C., and H. Venkataraman. 2017. Greening the economy: a review of urban sustainability measures for developing new cities. Sustainable Cities and Society 32:1-8. https://doi.org/10.1016/j.scs.2017.03.009

Alata Ninapaytán, P., A. C. Oshige Fernández, S. H. Quispe Mogrovejo, and D. B. Aguilar. 2019. ¿Cómo vamos en Lima y Callao? Noveno Informe de Indicadores sobre Calidad de Vida. Lima Como Vamos, Asociación Unacem, Villa Maria del Triunfo, Lima, Peru. [online] URL: http://www.limacomovamos.org/wpcontent/uploads/2019/11/Informe-2018 web.pdf 
Anderies, J. M., M. Katti, and E. Shochat. 2007. Living in the city: resource availability, predation, and bird population dynamics in urban areas. Journal of Theoretical Biology 247 (1):36-49. https://doi.org/10.1016/j.jtbi.2007.01.030

Aronson, M. F. J., F. A. La Sorte, C. H. Nilon, M. Katti, M. A. Goddard, C. A. Lepczyk, P. S. Warren, N. S. G. Williams, S. Cilliers, B. Clarkson, C. Dobbs, R. Dolan, M. Hedblom, S. Klotz, J. L. Kooijmans, I. Kuhn, I. MacGregor-Fors, M. McDonnell, U. Mortberg, P. Pysek, S. Siebert, J. Sushinsky, P. Werner, and M. Winter. 2014. A global analysis of the impacts of urbanization on bird and plant diversity reveals key anthropogenic drivers. Proceedings of the Royal Society B. 281:20133330. https://doi. org/10.1098/rspb.2013.3330

Azunre, G. A., O. Amponsah, C. Peprah, S. A. Takyi, and I. Braimah. 2019. A review of the role of urban agriculture in the sustainable city discourse. Cities 93:104-119. https://doi. org/10.1016/j.cities.2019.04.006

Bell, M. 2015. Historical political ecology of water: access to municipal drinking water in colonial Lima, Peru (1578-1700). Professional Geographer 67(4):504-526. https://doi. org/10.1080/00330124.2015.1062700

Bjerke, T., T. Østdahl, and J. Kleiven. 2015. Attitudes and activities related to urban wildlife: pet owners and non-owners. Anthrozoös 16(3):252-262. https://doi.org/10.2752/089279303786992125

Boster, J., B. Berlin, and J. O’Neill. 1986. The correspondence of Jivaroan to scientific ornithology. American Anthropologist 88 (3):569-583. https://doi.org/10.1525/aa.1986.88.3.02a00020

Botzat, A., L. K. Fischer, and I. Kowarik. 2016. Unexploited opportunities in understanding liveable and biodiverse cities: a review on urban biodiversity perception and valuation. Global Environmental Change 39:220-233. https://doi.org/10.1016/j. gloenvcha.2016.04.008

Brinkhoff, T. 2020. City Population. [online] URL: http://www. citypopulation.de

Browder, J. O., and B. J. Godfrey. 1997. Chapter 10: Frontier urbanization and environmental change in Amazonia. Pages 313-317 in J. O. Browder and B. J. Godfrey, editors. Rainforest cities: urbanization, development, and globalization of the Brazilian Amazon. Columbia University Press, New York, New York, USA.

Byrne, J. and J. Wolch. 2009. Nature, race, and parks: past research and future directions in geographic research. Progress in Human Geography 33(6):743-765. https://doi.org/10.1177/0309132509103156

Carruthers, C. 2018. Unapologetic: a Black, queer, and feminist mandate for radical movements. Beacon, Boston, Massachusetts, USA.

Castillo, O., C. Clark, P. Coppolillo, H. Kretser, R. McNab, A. Noss, H. Quieroz, Y. Tessema, A. Vedder, R. Wallace, J. Walston, and D. Wilkie. 2006. Working paper no. 28: Casting for conservation actors: people, partnerships, and wildlife. Wildlife Conservation Society, New York, New York, USA. [online] URL: https://pdf.usaid.gov/pdf docs/pbaaa183.pdf

Celis-Diez, J. L., C. E. Muñoz, S. Abades, P. A. Marquet, and J. J. Armesto. 2017. Biocultural homogenization in urban settings: public knowledge of birds in city parks of Santiago, Chile. Sustainability 9(4):485 https://doi.org/10.3390/su9040485

Chan, K. M. A., P. Balvanera, K. Benessaiah, M. Chapman, S. Díaz, E. Gómez-Baggethun, R. Gould, N. Hannahs, K. Jax, S. Klain, G. W. Luck, B. Martín-López, B. Muraca, B. Norton, K. Ott, U. Pascual, T. Satterfield, M. Tadaki, J. Taggart, and N. Turner. 2016. Why protect nature? Rethinking values and the environment. Proceedings of the National Academy of Sciences 113(6):1462-1465. https://doi.org/10.1073/pnas.1525002113

Chawla, L. 1999. Life paths into effective environmental action. Journal of Environmental Education 31(1):15-26. https://doi. org/10.1080/00958969909598628

Comtois, D. 2020. Summarytools: tools to quickly and neatly summarize data. R package version 0.9.6. [online] URL: https:// $\underline{\text { CRAN.R-project.org/package }=\text { summarytools }}$

Corburn, J. 2017. Urban place and health equity: critical issues and practices. International Journal of Environmental Research and Public Health 14(2):117. https://doi.org/10.3390/ijerph14020117

Cotterill, F. P. D. 1995. Systematics, biological knowledge, and environmental conservation. Biodiversity and Conservation 4:183-205. https://doi.org/10.1007/BF00137784

Cox, D. T. C., and K. J. Gaston. 2017. Human-nature interactions and the consequences and drivers of provisioning wildlife. Philosophical Transactions of the Royal Society B 373 (1745):20170092. https://doi.org/10.1098/rstb.2017.0092

Cronon, W. 1995. The trouble with wilderness; or, getting back to the wrong nature. Pages 69-90 in W. Cronon, editor. Uncommon ground: rethinking the human place in nature. W. W. Norton and Co., New York, New York, USA. https://doi. org/10.2307/3985059

de Groot, R. S., M. A. Wilson, and R. M. J. Boumans. 2002. A typology for the classification, description, and valuation of ecosystem functions, goods, and services. Ecological Economics 41(3):393-408. https://doi.org/10.1016/S0921-8009(02)00089-7

de Haen, H., K. Stamoulis, P. Shetty, and P. Pingali. 2003. The world food economy in the twenty-first century: challenges for international co-operation. Development Policy Review 21 (5-6):683-696. https://doi.org/10.1111/j.1467-8659.2003.00232.x

Derkzen, M., A. van Teeffelen, and P. Verburg. 2017. Green infrastructure for urban climate adaptation: how do residents' view on climate impacts and green infrastructure shape adaptation preferences? Landscape and Urban Planning 157:106-130. https://doi.org/10.1016/j.landurbplan.2016.05.027

Dickinson, E. 2013. The misdiagnosis: rethinking "nature-deficit disorder." Environmental Communication 7(3):315-335. https:// doi.org/10.1080/17524032.2013.802704

Diep, L., D. Dodman, and P. Parikh. 2019. Green infrastructure in informal settlements through a multiple-level perspective. Water Alternatives 12(2):554-570. [onlnie] URL: https://www. water-alternatives.org/index.php/alldoc/articles/vol12/v12issue3/542a12-2-25/file

Ewing, R. 1997. Is Los Angeles-style sprawl desirable? Journal of the American Planning Association 631(1):107-126. https://doi. org/10.1080/01944369708975728 
Figallo, M., and K. Vergara. 2014. La Amazonía peruana hoy. 2014. In R. Barrantes and M. Glave, editors. Amazonía peruana y desarrollo económico. IEP y GRADE, Lima, Peru.

Florczyk, A., C. Corbane, M. Schiavina, M. Pesaresi, L. Maffenini, M. Melchiorri, P. Politis, F. Sabo, S. Freire, D. Ehrlich, T. Kemper, P. Tommasi, D. Airaghi, and L. Zanchetta. 2019. GHS UrbanCentre Database 2015, multitemporal and multidimensional attributes, R2019A. Publications Office of the European Union, Luxembourg, Luxembourg. [online] URL: https://data.jrc.ec. europa.eu/dataset/53473144-b88c-44bc-b4a3-4583ed1f547e

Google Earth V 7.3.2.5776. May 25, 2016. Nauta, Peru. 4 30' 19.29”S, 73³4'51.55”W, Eye alt 3493 feet. CNES/Airbus 2019. [online] URL: http://www.earth.google.com

Gumucio, S., M. Merica, N. Luhman, G. Fauvel, S. Zompi, A. Ronsse, A. Courcaud, M. Bouchon, C. Trehin, S. Schapman, O. Cheminat, H. Ranchal, and S. Simon. 2011. The KAP survey model knowledge, attitude and practices. Médecins du Monde, Paris, France. [online] URL: https://www.medecinsdumonde.org/ en/actualites/publications/2012/02/20/kap-survey-model-knowledgeattitude-and-practices

Güneralp, B., Y. Zhou, D. Ürge-Vorzatz, M. Gupta, S. Yu, P. L. Patel, M. Fragkias, X. Li, and K. Seto. 2017. Global scenarios of urban density and its impacts on building energy use through 2050. Proceedings of the National Academy of Sciences 114 (34):8945-8950. https://doi.org/10.1073/pnas.1606035114

Hassell, J. M., M. Begon, M. J. Ward, and E. M. Fèvre. 2017. Urbanization and disease emergence: dynamics at the wildlifelivestock-human interface. Trends in Ecology and Evolution 32 (1):55-67. https://doi.org/10.1016/j.tree.2016.09.012

Hecht, S., M. Schmink, R. Abers, E. Assad, D. H. Bebbington, E. Brondizio, F. Costa, A. M. Durán Calisto, P. Fearnside, R. Garrett, S. Heilpern, D. McGrath, G. Oliveira, H. Pereira, and M. Pinedo-Vazquez. 2021. Amazon in motion: changing politics, development strategies, peoples, landscapes, and livelihoods. Chapter 14 in C. Nobre et al., editors. Science Panel for the Amazon: Amazon Assessment Report 2021. United Nations Sustainable Development Solutions Network, New York, USA. [online] URL: https://www.theamazonwewant.org/wp-content/ uploads/2021/11/211112-Amazon-Assessment-Report-2021-PartII-reduced.pdf

Heckenberger, M. J., A. Kuikuro, U. T. Kuikuro, J. C. Russell, M. Schmidt, C. Fausto, and B. Franchetto. 2014. Amazonia 1492: pristine forest or cultural parkland? Pages 315-321 in S. B. Hecht, K. D. Morrison, and C. Padoch, editors. The social lives of forests. University of Chicago Press, Chicago, Illinois, USA.

Instituto Nacional de Estadística e Informática (INEI). 2017. Peru: resultados definitivos de los censos 2017. INEI, Lima, Peru. [online] URL: https://www.inei.gob.pe/media/MenuRecursivo/ publicaciones digitales/Est/Lib1544/

Ioris, A. A. R. 2012. The geography of multiple scarcities: urban development and water problems in Lima, Peru. Geoforum 43:612-622. https://doi.org/10.1016/j.geoforum.2011.12.005

Kahle, D., and H. Wickham. 2013. ggmap: Spatial Visualization with ggplot2. R Journal 5(1):144-161. https://doi.org/10.32614/ RJ-2013-014
Kassambara, A., and F. Mundt. 2020. Factoextra: extract and visualize the results of multivariate data analyses. $\mathrm{R}$ package version 1.0.7. [online] URL: https://CRAN.R-project.org/ package $=$ factoextra

Krasny, M. 2015. Extinction of experience: does it matter? Nature of cities. [online] ULR: https://www.thenatureofcities.com/2015/03/15/ extinction-of-experience-does-it-matter/

Kuhn, M. 2020. Caret: classification and regression training. R package version 6.0-86. [online] URL: https://CRAN.R-project. org/package $=$ caret

Lazarte, M. 2015. Estudio de las dinamicas y procesos de desarrollo economico territorial en una Lima policentrica. Consorcio de organizaciones privades de promoción al desarrollo de la micro y pequeña empresa (COPEME), Lima, Peru. [online] URL: http://www.conectadel.org/wp-content/uploads/downloads/2015/05/ Informe-Sistematizacion-DEL_Dinamicas-y-procesos-de-DEL-enuna-Lima-Policentrica 1 .pdf

Lê, S., J. Josse, F. Husson. 2008. FactoMineR: a package for multivariate analysis. Journal of Statistical Software 25(1):1-18. https://doi.org/10.18637/jss.v025.i01

Lin, B. B., R. A. Fuller, R. Bush, K. J. Gaston, and D. F. Shanahan. 2014. Opportunity or orientation? Who uses urban parks and why. PLoS ONE 9(1):e87422. https://doi.org/10.1371/journal. pone. 0087422

Lin, P., and Z. Gou. 2017. Effects of urban planning indicators on urban heat island: a case study of pocket parks in high-rise high-density environment. Landscape and Urban Planning 168:48-60. https://doi.org/10.1016/j.landurbplan.2017.09.024

Luck, G.W., L. T. Smallbone, and R. O’Brien. 2009. Socioeconomics and vegetation change in urban ecosystems: patterns in space and time. Ecosystems 12:604. https://doi.org/10.1007/ $\underline{\text { s10021-009-9244-6 }}$

Lumley, T., based on Fortran code by A. Miller. 2020. Leaps: regression subset selection. $\mathrm{R}$ package version 3.1. [online] URL: https://cran.r-project.org/web/packages/leaps/leaps.pdf

Marzluff, J. 2001. Chapter 2: Worldwide urbanization and its effects on birds. Pages 19-47 in J. Marzluff, R. Bowman, and R. Donnelly, editors. Avian Ecology and Conservation in an Urbanizing World. Springer New York, New York, USA. [online] URL: https://link.springer.com/content/pdf/10.1007\% 2F978-1-4615-1531-9 2.pdf

Masterson, V. A., S. Vetter, T. Chaigneau, T. M. Daw, O. Selomane, M. Hamann, G. Y. Wong, V. Mellegard, M. Cocks, and M. Tengo. 2019. Revisiting the relationships between human well-being and ecosystems in dynamic social-ecological systems: implications for stewardship and development. Global Sustainability 2:e8. https://doi.org/10.1017/sus.2019.5

Mayer, F. S., and C. M. Frantz. 2004. The connectedness to nature scale: a measure of individuals' feeling in community with nature. Journal of Environmental Psychology 24(4):503-515. https://doi. org/10.1016/j.jenvp.2004.10.001

McKinley, M. L. 2006. Urbanization as a major cause of biotic homogenization. Biological Conservation 127(3):247-260. https://doi.org/10.1016/j.biocon.2005.09.005 
Mendham, E., and A. Curtis. 2010. Taking over the reins: trends and impacts of changes in rural property ownership. Society and Natural Resources 23(7):653-668. https://doi.org/10.1080/08941920801998893

Ministerio de Transportes y Comunicaciones. 2008. Informe final: consorcio hidrovía Amazonas, contrato No. 056-2007-MTC10. Ministerio de Transportes y Comunicaciones, Lima, Peru. [online] URL: https://portal.mtc.gob.pe/transportes/acuatico/ documentos/estudios/Informaci $\% \mathrm{C} 3 \% \mathrm{~B} 3 \mathrm{n} \% 20$ Socioecon $\% \mathrm{C} 3 \%$ B3mica.pdf

Miller, J. R. 2005. Biodiversity conservation and the extinction of experience. Trends in Ecology and Evolution 20(8):430-434. https://doi.org/10.1016/j.tree.2005.05.013

Mock, B. 2017. The green movement is talking about racism? It's about time. Outside Magazine. https://www.outsideonline. com/2142326/environmentalism-must-confront-its-social-justicesins\#close

O'Brien, W. E. 2015. Landscapes of exclusion: state parks and Jim Crow in the American South. University of Massachusetts Press, Amherst, Massachusetts, USA.

Ogden, J. C., J. D. Baldwin, O. L. Bass, J. A. Browder, M. I. Cook, P. C. Frederick, P. E. Frezza, R. A. Galvez, A. B. Hodgson, K. D. Meyer, L. D. Oberhofer, A. F. Paul, P. J. Fletcher, S. M. Davis, and J. J. Lorenz. 2014. Waterbirds as indicators of ecosystem health in the coastal marine habitats of southern Florida: 1. Selection and justification for a suite of indicator species. Ecological Indicators 44:148-163. https://doi.org/10.1016/j. ecolind.2014.03.007

Olivos, P., J. I. Aragones, and M. Amerigo. 2011. The connectedness to nature scale and its relationship with environmental beliefs and identity. IPHJ 4(1):5-19. [online] URL: https://www.researchgate.net/profile/Juan-Aragones-2/

publication/236172119 The connectedness to nature scale an$\underline{\mathrm{d} \text { its relationship with environmental beliefs and identity/ }}$

links/0c96052d063a8b95d3000000/The-connectedness-to-naturescale-and-its-relationship-with-environmental-beliefs-and-identity. pdf

Padoch, C., A. Steward, M. Pinedo-Vasquez, L. Putzel, and M. Miranda Ruiz. 2014. Urban residence, rural employment, and the future of Amazonian forests. 2014. Pages 322-335 in S. B. Hecht, K. D. Morrison, and C. Padoch, editors. The social lives of forests. University of Chicago Press, Chicago, Illinois, USA. https://doi. org/10.7208/chicago/9780226024134.003.0030

Perrin, J. L., and V. A. Benassi. 2009. The connectedness to nature scale: a measure of emotional connection to nature? Journal of Environmental Psychology 29(4):434-440. https://doi.org/10.1016/ j.jenvp.2009.03.003

Piland, N. 2020. People, cities, and birds in Latin America. Dissertation. University of Chicago, Chicago, Illinois, USA. [online] URL: https://knowledge.uchicago.edu/record/2739

Primack, R. B. 2014. Essentials of conservation biology, 4th ed. Sinauer Associates, Sunderland, Massachusetts, USA.

Pyle, R. M. 1978. The extinction of experience. Horticulture 56:64-67.
Pyle, R. 2003. Nature matrix: reconnecting people and nature. Oryx 37(2):206-214. https://doi.org/10.1017/S0030605303000383

R Core Team. 2020. R: a language and environment for statistical computing. R Foundation for Statistical Computing, Vienna, Austria. [online] URL: https://www.R-project.org/

Robinson, S. 2019. Bird niches in human culture and why they matter. Proceedings of the National Academy of Sciences 116 (22):10620-10622. https://doi.org/10.1073/pnas.1905901116

RStudio Team. 2020. RStudio: integrated development for R. RStudio, Boston, Massachusetts, USA. [online] URL: https:// www.rstudio.com/

Sanderson, E., J. Walston, and J. G. Robinson. 2018. From bottleneck to breakthrough: urbanization and the future of biodiversity conservation. BioScience 68(6):412-426. https://doi. org/10.1093/biosci/biy039

Santos Baquero, O. 2019. ggsn: North Symbols and Scale Bars for Maps created with 'ggplot2' or 'ggmap'. R package version 0.5.0. [online] URL: https://CRAN.R-project.org/package=ggsn

Schuttler, S. G., A. E. Sorensen, R. C. Jordan, C. Cooper, and A. Shwartz. 2018. Bridging the nature gap: can citizen science reverse the extinction of experience? Frontiers in Ecology and the Environment 16(7):405-411. https://doi.org/10.1002/fee.1826

Soga, M., and M. Akasaka. 2019. Multiple landscapemanagement and social-policy approaches are essential to mitigate the extinction of experience. Landscape and Urban Planning 191:103634. https://doi.org/10.1016/j.landurbplan.2019.103634

Soga, M., and K. J. Gaston. 2016. Extinction of experience: the loss of human-nature interactions. Frontiers in Ecology and the Environment 14(2):94-101. https://doi.org/10.1002/fee.1225

Sol, D., C. Trisos, C. Murria, A. Jeliaskov, C. Gonzalez-Lagos, A. L. Pigot, C. Ricotta, C. M. Swan, J. A. Tobias, and S. Pavoine. 2020. The worldwide impact of urbanization on avian functional diversity. Ecology Letters 23(6):962-972. https://doi.org/10.1111/ ele. 13495

Spickard, P. R., R. Fong, and P. L. Ewalt. 1995. Undermining the very basis of racism - its categories. Social Work 40(5):581-584. https://doi.org/10.1093/sw/40.5.581

Stiman, M. 2020. Second homes in the city and the country: a reappraisal of vacation homes in the twenty-first century. International Journal of Housing Policy 20(1):53-74. https://doi. org/10.1080/19491247.2019.1627842

United States. 2017. North American industry classification system. U.S. Census Bureau, Suitland, Maryland, USA. [online] URL: https://www.census. gov/naics/?58967?yearbck=2017

Wali, A., D. Alvira, P. S. Tallman, A. Ravikumar, and M. O. Macedo. 2017. A new approach to conservation: using community empowerment for sustainable well-being. Ecology and Society 22(4):6. https://doi.org/10.5751/ES-09598-220406

Wang, C., and M. A. Burris. 1997. Photovoice: concept, methodology, and use for participatory needs assessment. Health Education \& Behavior 24(3):369-387. https://doi.

org/10.1177/109019819702400309 
Wang, H., C. W. Marshall, M. Cheng, H. Xu, H. Li, X. Yang, and T. Zheng. 2017. Changes in land use driven by urbanization impact nitrogen cycling and the microbial community composition in soils. Scientific Reports 7:44049. https://doi. org/10.1038/srep44049

Wickham, H., M. Averick, J. Bryan, W. Chang, L. D. McGowan, R. Francois, G. Grolemund, A. Hayes, L. Henry, J. Hester, M. Kuhn, T. L. Pedersen, E. Miller, S. M. Bache, K. Muller, J. Ooms, D. Robinson, D. P. Seidel, V. Spinu, K. Takahashi, D. Vaughan, C. Wilke, K. Woo, and H. Yutani. 2019. Welcome to the tidyverse. Journal of Open Source Software 4(43):1686. https://doi. org/10.21105/joss.01686

Wright, P. A., and C. Matthews. 2015. Building a culture of conservation: research findings and research priorities on connecting people to nature in parks. PARKS 21(2):11-24. https:// doi.org/10.2305/IUCN.CH.2014.PARKS-21-2PAW.en

Wolch, J., J. Byrne, and J. Newell. 2014. Urban green space, public health, and environmental justice: the challenge of making cities 'just green enough.' Landscape and Urban Planning 125:234-244. https://doi.org/10.1016/j.landurbplan.2014.01.017

Wood, C., B. Sullivan, M. Iliff, D. Fink, and S. Kelling. 2011. eBird: engaging birders in science and conservation. PLoS Biology 9(12):e1001220. https://doi.org/10.1371/journal.pbio.1001220

Zaradic, P. A., O. R. W. Pergams, and P. Kareiva. 2009. The impact of nature experience on willingness to support conservation. PLoS ONE 4(10):e7367. https://doi.org/10.1371/journal.pone.0007367

Zhang, J. W., and R. Iyer. 2014. Engagement with natural beauty moderates the positive relation between connectedness with nature and psychological well-being. Journal of Environmental Psychology 38:55-63. https://doi.org/10.1016/j.jenvp.2013.12.013 
Appendix 1. Survey materials

\section{Lenguaje para pedir permiso}

Por favor considere participar en esta encuesta voluntaria. La encuesta solo debe tomar 10 minutos para completar y los datos no estarán vinculados a su identidad. Como investigadores, estamos tratando de entender cómo la gente de esta ciudad interactúa con la naturaleza y cuánto conoce de las aves en su alrededor. Estos datos se usarán para la tesis de doctorado de la Biologa Natalia Piland. Puede contactarla con cualquier pregunta al correo: npiland@uchicago.edu

\section{Encuesta}

Nota para el/la encuestador/a: Esta encuesta se ha diseñado para entender algunos factores que podrían afectar cómo un/a ciudadan@ se relaciona con la naturaleza en su vecindario/barrio. Entre estos factores se encuentran edad, nivel de educación, duración en el barrio, origen, tiempo que se realiza y tipo de actividades realizados afuera. La relación que se percibe en esta encuesta con la naturaleza es conocimiento de aves y motivación en conocer más sobre las aves. Esto se correlacionará con información obtenida sobre cada localidad en cuanto a diversidad de aves observado y algunos factores ambientales cómo porcentaje de áreas verdes que se medirán a través del monitoreo remoto.

Localidad:

Fecha:

\section{Encuestador/a:}

Encuestad@ (Si se siente comod@):

¿Cuál es su fecha de nacimiento?

¿Cómo se identifica en cuanto a género?

¿Qué nivel de estudios tiene?

Primaria Completa / Primaria Incompleta

Secundaria Completa / Secundaria Incompleta

Estudios técnicos completos / incompletos

Universitario completo/ incompleto

Posgrado completo/incompleto

¿A qué se dedica? ¿En qué trabaja?

¿Desde que año usted vive en este barrio?

¿Dónde vivía antés de mudarse a este barrio?

¿Qué tipo de actividades realiza afuera de su casa en el barrio?

Sentarse a tomar sol/respirar aire fresco

Caminar por el barrio/en un parque cercano

Jugar deportes

Otro:

¿Cuántas horas semanales pasa realizando esas actividades?

Poco (1 hora/semana - 4 horas/semana)

Regular (4 - 10 horas/semana)

Mucho (10+ horas/semana)

¿Tiene mascotas?

¿Cuáles y cuántas? 
¿Los deja salir afuera?

¿Tiene un jardín?

¿Qué tipos de plantas tiene en el jardín?

¿Ud. ha observado aves en el barrio?

¿Aproximadamente cuántos diferentes tipos de aves estima que ha visto aquí?

¿Puede nombrar algunas de las aves que ha visto?

En su opinión, estima que la diversidad de aves que hay en este vecindario es:

Sólo hay pocos tipos de aves

Normal

Muchos diferentes tipos de aves

No sabe

¿Conoce el nombre de las siguientes aves? (Enseñar lamina de aves)

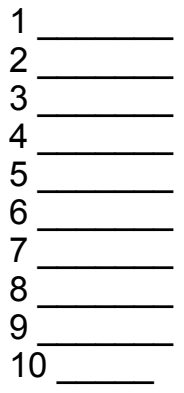

¿Le gustaría más información de las aves que se encuentran aquí? Sí / NO

¿Qué tipo de información le gustaría obtener?

Comentarios sobre las láminas: Las láminas incluyen las diez especies que se encontraron ser más abundantes en cada ciudad de interés durante conteos de aves en el 2017. La lámina de Huacho tiene diez especies, pero solo nueve cuentan (hubo un fallo que no se percató hasta después de completar la mayoría de las encuestas). El nombre científico para cada ave se encuentra en la siguiente tabla. Las aves correspondientes se encuentran empezando por la ave en la esquina superior a la izquierda, siguiendo de izquierda a derecha y por file de arriba hacia abajo. Si la ave es introducida, se encuentra "(I)" después de su nombre científico. Las aves no están en orden de abundancia.

Table A1.1 Scientific names for birds in figures A1.1-4. | Nombres cientificos para las aves en figuras A1.1-4.

\begin{tabular}{|l|l|l|l|}
\hline Iquitos (Fig. A1.1) & Nauta (Fig. A1.2) & Lima (Fig. A1.3) & Huacho (Fig. A1.4) \\
\hline $\begin{array}{l}\text { Columba livia (I) } \\
\text { Phalacrocorax brasilianus }\end{array}$ & Columba livia (I) & Coereba flaveola & Cathartes aura \\
\hline Coragyps atratus & Coragyps atratus & Psittacara erythrogenys & Coragyps atratus \\
\hline
\end{tabular}




\begin{tabular}{|c|c|c|c|}
\hline Iquitos (Fig. A1.1) & Nauta (Fig. A1.2) & Lima (Fig. A1.3) & Huacho (Fig. A1.4) \\
\hline Hirundo rustica & Tachornis squamata & Pyrocephalus rubinus & $\begin{array}{l}\text { PAJARO EQUIVOCADO } \\
\text { INCORRECT BIRD }\end{array}$ \\
\hline Brotogeris cyanoptera & Brotogeris cyanoptera & Pygochelidon cyanoleuca & Pygochelidon cyanoleuca \\
\hline Brotogeris versicolorus & Brotogeris versicolorus & Molothrus bonariensis & Passer domesticus (I) \\
\hline Aratinga weddellii & Graydidascalus brachyurus & Larus dominicanus & Columbina cruziana \\
\hline Thraupis episcopus & Egretta thula & Columba livia (I) & Columba livia (I) \\
\hline Tyrannus melancholicus & Thraupis episcopus & Zenaida meloda & Zenaida meloda \\
\hline Pitangus sulphuratus & Cacicus cela & Columbina cruziana & Zenaida auriculata \\
\hline
\end{tabular}

\section{Translation for English Speakers}

\section{Consent Language}

Please consider participating in our voluntary survey. The survey should only take 10 minutes to complete and the data will not be linked to your identity. As researchers, we are trying to understand how people in this city interact with nature and how well they know the birds in their surroundings. These data will be used for biologist Natalia Piland's doctoral thesis. If you would like to ask questions, please contact her at the email: npiland@uchicago.edu

\section{Survey}

Note for the surveyor: This survey is designed to understand some factors that may affect how a resident relates to nature in their neighborhood. These factors include age, education level, residency length, where they're from, how much time is spent on which activities outside. The human-nature relationship assessed in this survey is knowledge of birds and motivation in knowing more about birds. This will be correlated with information about each site, including birds observed and some environmental factors like percent of green areas (quantified through remote sensing).

Site:

Date:

Surveyer:

Surveyed (If they feel comfortable):

1. ¿What is your birth date?

2. ¿How do you identify in terms of gender?

3. ¿What is your highest level of education?

Completed Primary / Incomplete Primary

Completed Secondary / Incomplete Secondary

Completed Technical Studies / Incomplete Technical Studies

Completed University / Incomplete University

Completed Post-graduate / Incomplete Post-graduate

4. ¿What's your profession? 
5. ¿Since what year do you live in this neighborhood?

6. ¿Where did you live before you moved to this neighborhood?

7. ¿What type of activities do you engage in outside in your neighborhood?

Sit to sunbathe and breathe fresh air

Walk in the neighborhood/to a nearby park

Play Sports

Other:

8. ¿How many hours a week do you spend outside?

Small amount (1 hour/week -4 hours/week)

Regular amount (4 - 10 hours/week)

Large amount (10+ hours/week)

9. ¿Do you have pets?

¿Which and how many?

¿Are they allowed outside?

10. ¿Do you have a garden?

¿What types of plants do you have in the garden?

11. ¿Have you noticed birds in your neighborhood?

12. ¿Approximately how many types of birds have you seen in your neighborhood?

13. ¿Can you name some of the birds you've seen?

14. In your opinion, do you estimate that the diversity of birds in this neighborhood is:

There are only a few types of birds

Normal

There are many types of birds

I don't know

15. ¿Do you know the name of these birds? (Show laminated sheet with birds)

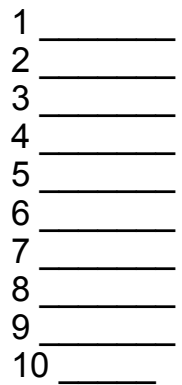

16. ¿Would you like to know more about the birds you can find in this neighborhood? YES / NO

17. ¿What type of information would you like to learn?

Commentary regarding the following figures: These laminated sheets (presented as figures) include the ten most abundant species according to the bird counts from 2017. The laminated sheet for Huacho 
has ten species, but only nine contributed to the analysis (there was a mistake that was not caught until the majority of surveys had been implemented). The scientific name for each bird is presented in table A1.1 seen above. The order to read the laminated sheets is from the uppermost left corner, going left to right, then going down each row. If the bird is introduced there is an "I" after the scientific name. The birds are not in order of abundance. 
Figures A1.1-4. Bird identification sheets for: (1) Iquitos; (2) Nauta; (3) Lima; and (4) Huacho. Note that in Supp-1Cd (Huacho), everything was calculated out of nine rather than ten, because Sporophila sp. pictured does not occur in Huacho.

Fig. A1.1

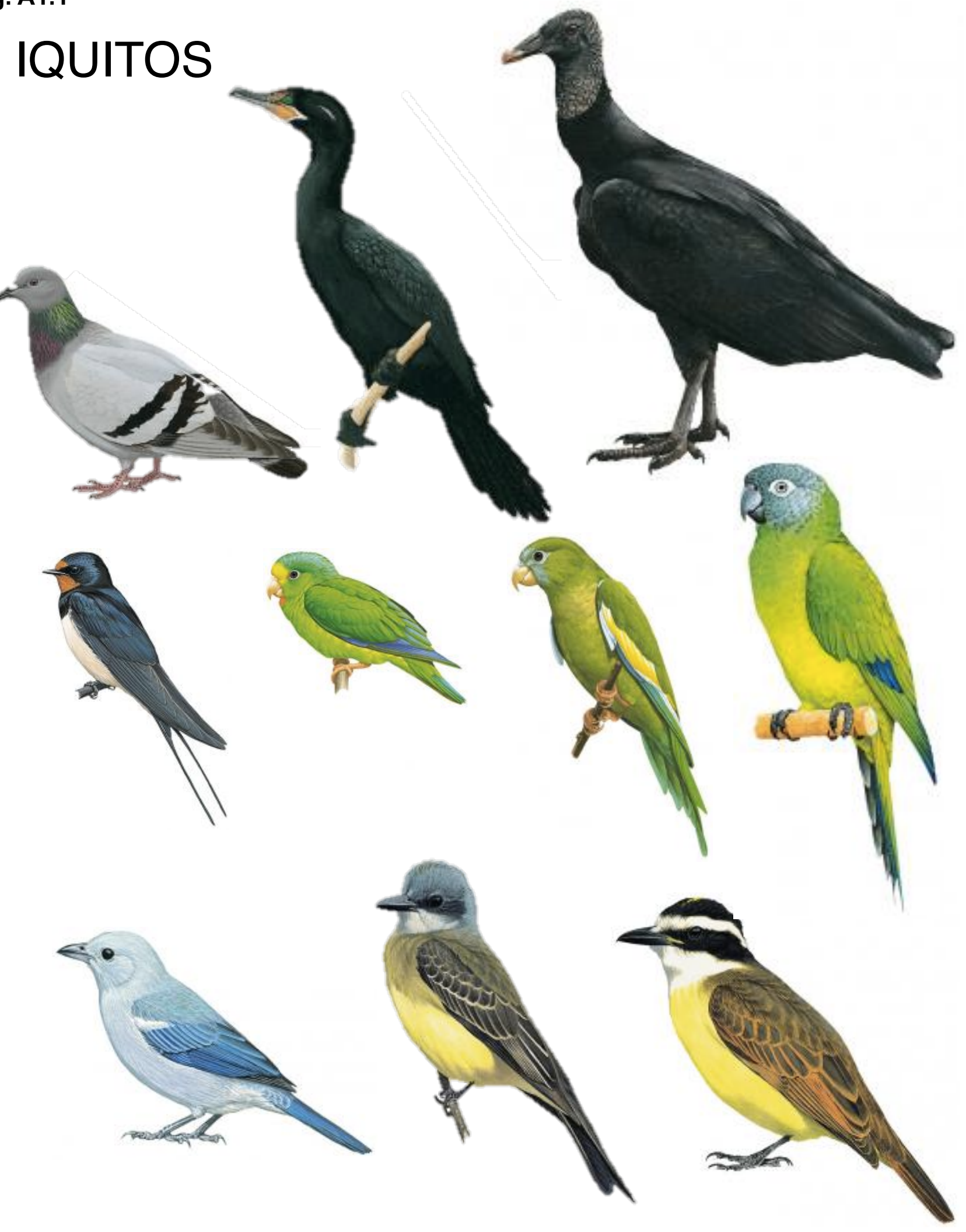


Fig. A1.2

NAUTA
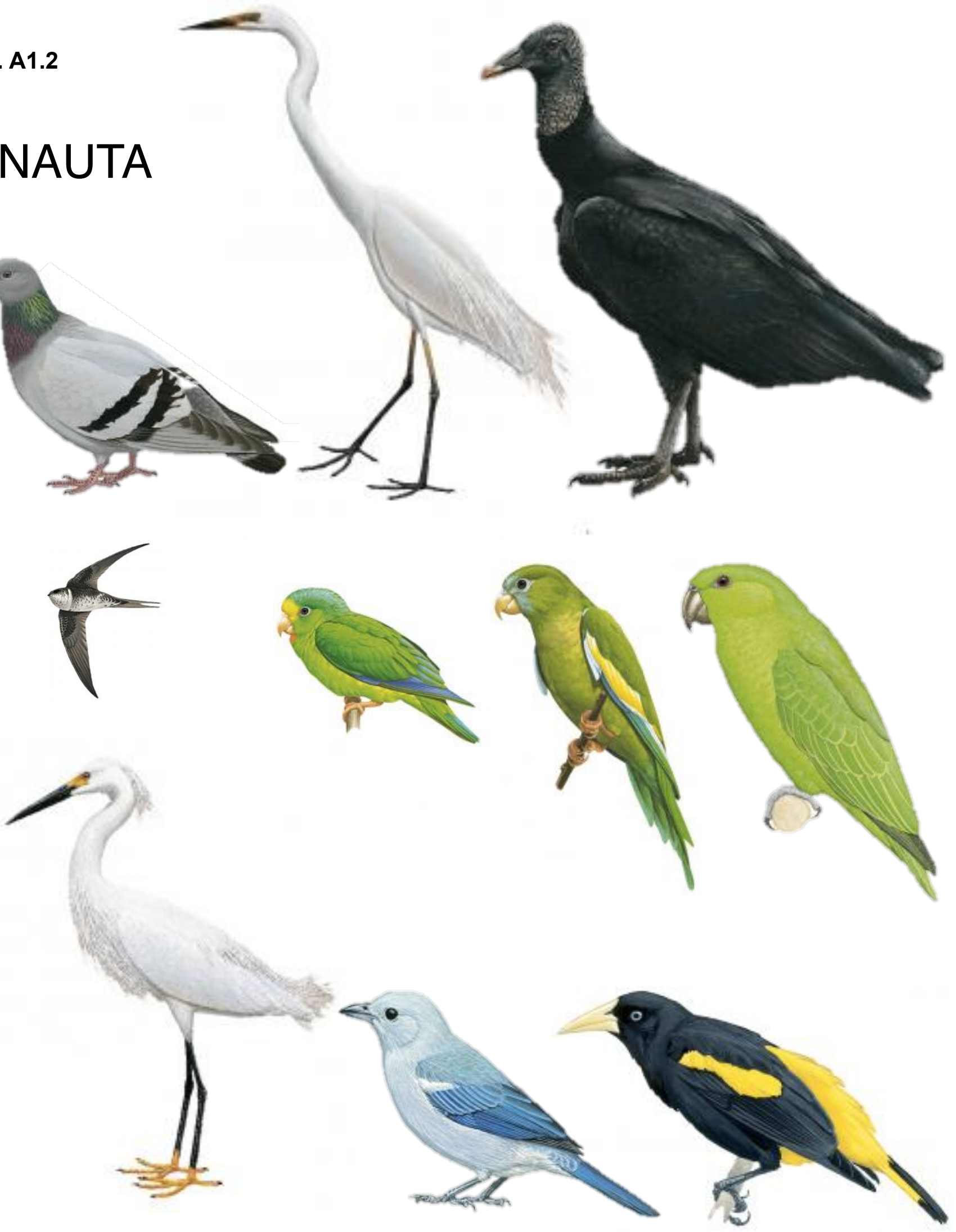
Fig. A1.3

LIMA
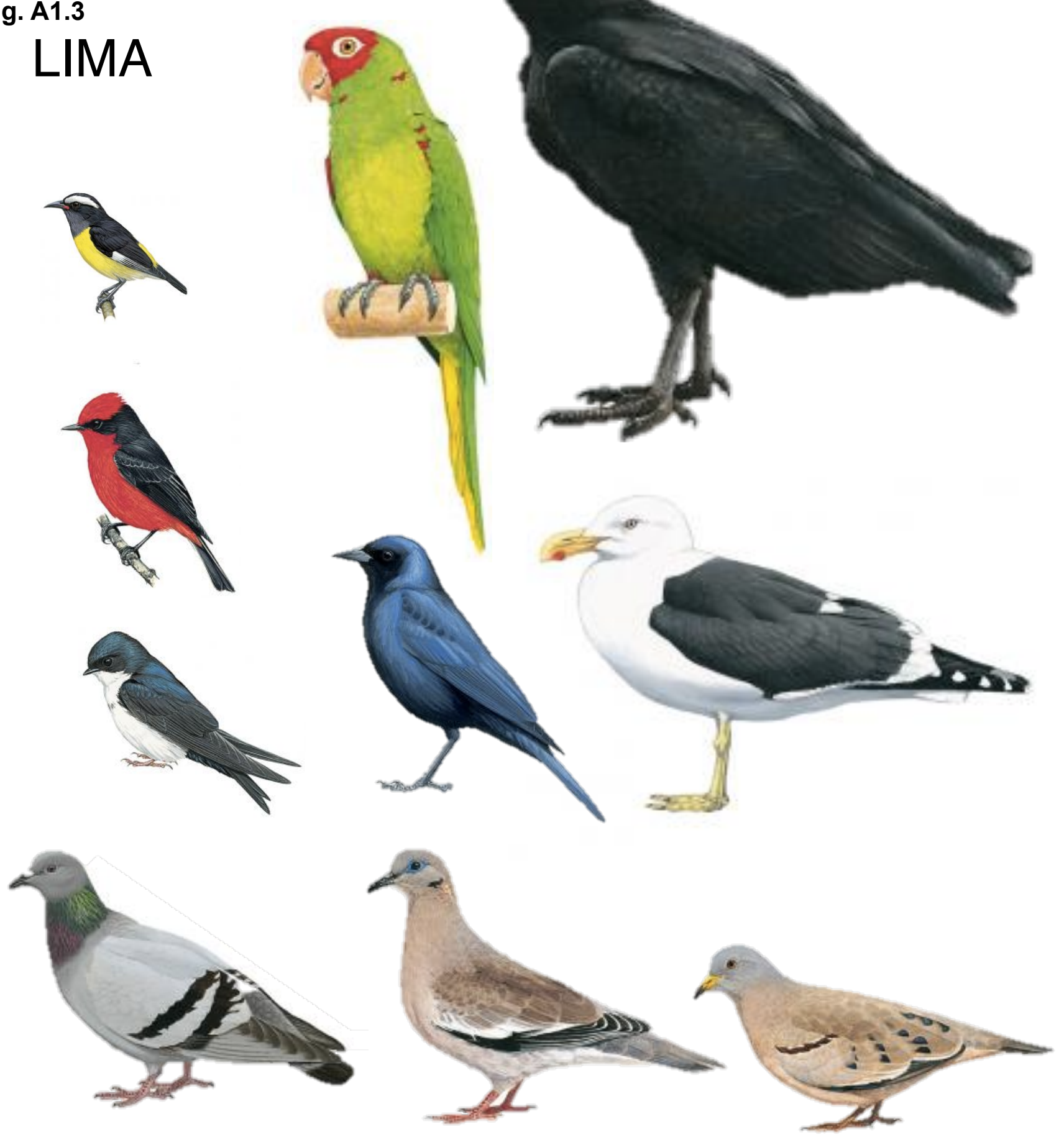
Fig. A1.4

HUACHO
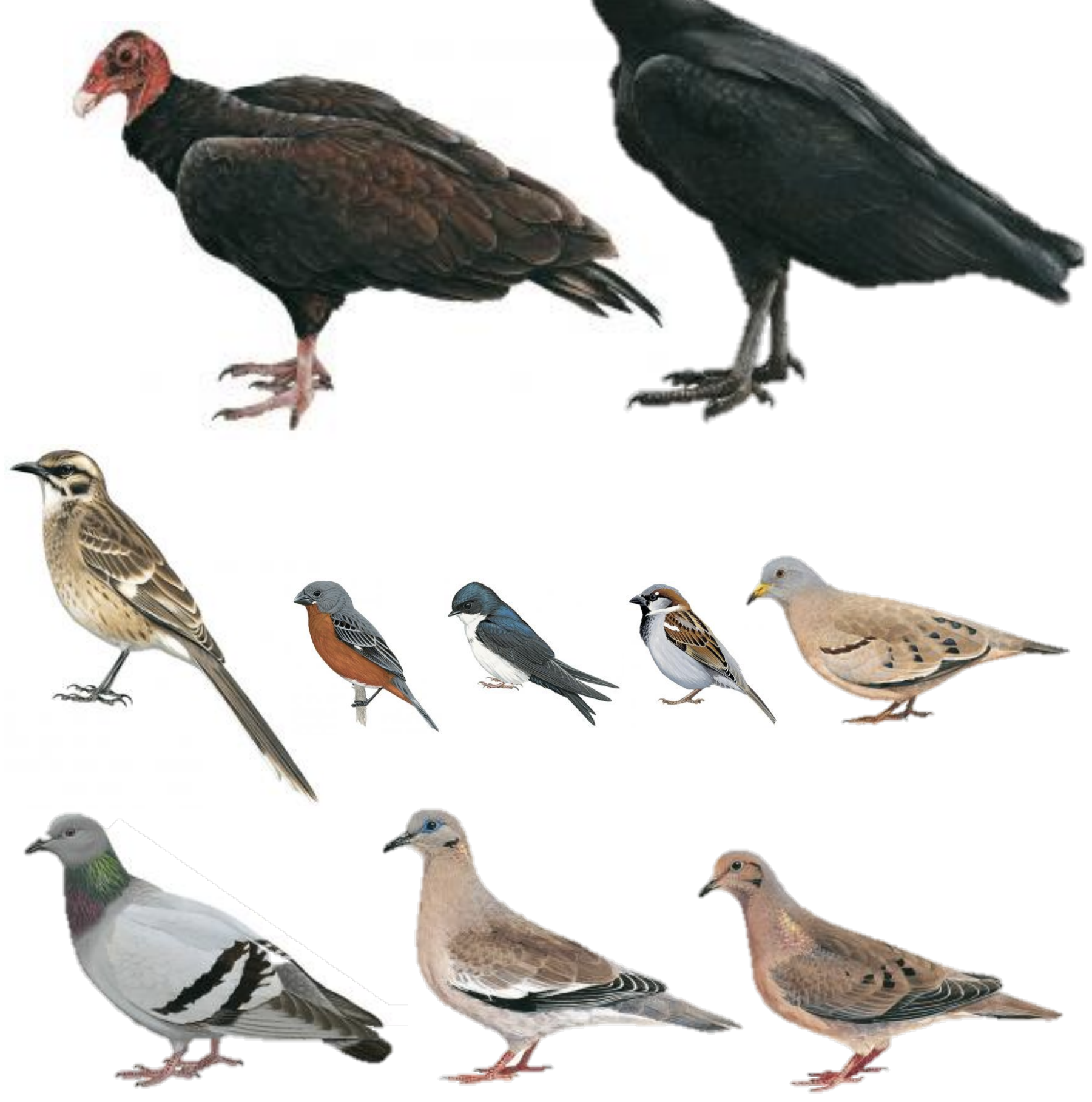


\section{Appendix 2. Descriptive Statistics}

Table A2.1. Table summarizing all independent variables from the survey by city, and then in total. For categorical variables raw numbers are presented with their proportion of the group in parenthesis. For quantitative variables, distribution parameters minimum, mean, standard deviation, median, and maximum are presented for each group. 963 individuals were surveyed in total.

\begin{tabular}{|c|c|c|c|c|c|}
\hline Variable & $\begin{array}{l}\text { City } \\
\text { Huacho }\end{array}$ & Lima & Iquitos & Nauta & Total \\
\hline \multicolumn{6}{|l|}{ Gender Presentation } \\
\hline Feminine & $96(53.3 \%)$ & $174(52.7 \%)$ & $193(55.1 \%)$ & $44(43.6 \%)$ & $507(52.8 \%)$ \\
\hline Masculine & $79(43.9 \%)$ & $151(45.8 \%)$ & $156(44.6 \%)$ & $57(56.4 \%)$ & $443(46.1 \%)$ \\
\hline No Response & $5(2.8 \%)$ & $5(1.5 \%)$ & $1(0.3 \%)$ & $0(0.0 \%)$ & $11(1.15 \%)$ \\
\hline Total & 180 & 330 & 350 & 101 & 961 \\
\hline \multicolumn{6}{|l|}{ Age } \\
\hline Mean (sd) & $41.3(19.3)$ & $43.3(19.4)$ & $40.8(18.5)$ & $41.4(16.1)$ & $41.8(18.7)$ \\
\hline Minimum & 7 & 7 & 4 & 12 & 4 \\
\hline Median & 38 & 42 & 39 & 42 & 40 \\
\hline Maximum & 86 & 92 & 86 & 78 & 92 \\
\hline No Response & 3 & 9 & 1 & 0 & 13 \\
\hline \multicolumn{6}{|l|}{ Education } \\
\hline None & $0(0 \%)$ & $0(0 \%)$ & $4(1.1 \%)$ & $1(1.0 \%)$ & $5(0.5 \%)$ \\
\hline Primary - Incomplete & $6(3.3 \%$ & $10(3.0 \%)$ & $24(6.9 \%)$ & $18(17.8 \%)$ & $58(6.0 \%)$ \\
\hline Primary - Complete & $13(7.2 \%)$ & $21(6.4 \%)$ & $20(5.7 \%)$ & $10(9.9 \%)$ & $64(6.7 \%)$ \\
\hline Secondary - Incomplete & $22(12.2 \%)$ & $27(8.2 \%)$ & $63(18 \%)$ & $19(18.8 \%)$ & $131(13.7 \%)$ \\
\hline Secondary - Complete & $65(36.1 \%)$ & $0(0 \%)$ & $98(28 \%)$ & $21(20.8 \%)$ & $184(19.1 \%)$ \\
\hline Technical Studies - Incomplete & $2(1.1 \%)$ & $14(4.3 \%)$ & $13(3.7 \%)$ & $1(1.0 \%)$ & $30(3.1 \%)$ \\
\hline Technical Studies - Complete & $17(9.4 \%)$ & $45(13.6 \%)$ & $37(10.6 \%)$ & $10(9.9 \%)$ & $109(11.3 \%)$ \\
\hline University - Incomplete & $15(8.3 \%)$ & $31(9.4 \%)$ & $38(10.9 \%)$ & $3(3.0 \%)$ & $87(9.0 \%)$ \\
\hline University - Complete & $33(18.3 \%)$ & $172(52.1 \%)$ & $53(15.1 \%)$ & $17(16.8 \%)$ & $275(28.6 \%)$ \\
\hline Postgraduate & $2(1.1 \%)$ & $4(1.2 \%)$ & $0(0.0 \%)$ & $1(1.0 \%)$ & $7(0.7 \%)$ \\
\hline No Response & $5(2.8 \%)$ & $6(1.8 \%)$ & $0(0.0 \%)$ & $0(0.0 \%)$ & $11(1.1 \%)$ \\
\hline Total & $180(100 \%)$ & $330(100 \%)$ & $350(100 \%)$ & $101(100 \%$ & $961(100 \%)$ \\
\hline
\end{tabular}




\begin{tabular}{|c|c|c|c|c|c|}
\hline Variable & $\begin{array}{l}\text { City } \\
\text { Huacho }\end{array}$ & Lima & Iquitos & Nauta & Total \\
\hline \multicolumn{6}{|l|}{ Work } \\
\hline Accommodation and Food Services & $5(2.8 \%)$ & $7(2.1 \%)$ & $5(1.4 \%)$ & $0(0.0 \%)$ & $17(1.8 \%)$ \\
\hline Administrative and Support Services & $4(2.2 \%)$ & $22(6.6 \%)$ & $7(2.0 \%)$ & $0(0.0 \%)$ & $33(3.4 \%)$ \\
\hline Agriculture, Forestry, Fishing, and Hunting & $7(3.9 \%)$ & $0(0.0 \%)$ & $3(0.9 \%)$ & $15(14.9 \%)$ & $25(2.6 \%)$ \\
\hline Arts, Entertainment, and Recreation & $3(1.7 \%)$ & $7(2.1 \%)$ & $5(1.4 \%)$ & $1(1.0 \%)$ & $16(1.7 \%)$ \\
\hline Construction & $5(2.8 \%)$ & $4(1.2 \%)$ & $9(2.6 \%)$ & $6(5.9 \%)$ & $24(2.5 \%)$ \\
\hline Educational Services & $4(2.2 \%)$ & $9(2.7 \%)$ & $21(6.0 \%)$ & $1615.8 \%)$ & $50(5.2 \%)$ \\
\hline Finance and Insurance & $1(0.6 \%)$ & $8(2.4 \%)$ & $0(0.0 \%)$ & $0(0.0 \%)$ & $9(0.9 \%)$ \\
\hline Freelance & $12(6.7 \%)$ & $11(3.3 \%)$ & $37(10.6 \%)$ & $7(6.9 \%)$ & $67(7.0 \%)$ \\
\hline Health Care and Social Assistance & $5(2.8 \%)$ & $10(3.0 \%)$ & $4(1.1 \%)$ & $1(1.0 \%)$ & $20(2.1 \%)$ \\
\hline Information & $1(0.6 \%)$ & $2(0.6 \%)$ & $0(0.0 \%)$ & $0(0.0 \%)$ & $3(0.3 \%)$ \\
\hline Management of Companies and Enterprises & $7(3.9 \%)$ & $9(2.7 \%)$ & $0(0.0 \%)$ & $0(0.0 \%)$ & $16(1.7 \%)$ \\
\hline Manufacturing & $2(1.1 \%)$ & $4(1.2 \%)$ & $4(1.1 \%)$ & $0(0.0 \%)$ & $10(1.0 \%)$ \\
\hline Mining, Quarrying, Oil, and Gas Extraction & $0(0.0 \%)$ & $1(0.3 \%)$ & $0(0.0 \%)$ & $0(0.0 \%)$ & $1(0.1 \%)$ \\
\hline Other Services & $45(25.0 \%)$ & $63(19.0 \%)$ & $79(22.6 \%)$ & $28(27.7 \%)$ & $215(22.4 \%)$ \\
\hline Professional, Scientific, and Technical Services & $2(1.1 \%)$ & $12(3.6 \%)$ & $12(3.4 \%)$ & $2(2.0 \%)$ & $28(2.9 \%)$ \\
\hline Public Administration & $3(1.7 \%)$ & $10(3.0 \%)$ & $9(2.6 \%)$ & $0(0.0 \%)$ & $22(2.3 \%)$ \\
\hline Retail Trade & $17(9.4 \%)$ & $34(10.3 \%)$ & $62(17.7 \%)$ & $10(9.9 \%)$ & $123(12.8 \%)$ \\
\hline Retired & $14(7.8 \%)$ & $29(8.7 \%)$ & $10(2.9 \%)$ & $0(0.0 \%)$ & $53(5.6 \%)$ \\
\hline Student & $33(18.3 \%)$ & $51(15.4 \%)$ & $61(17.4 \%)$ & $11(10.9 \%)$ & $156(16.2 \%)$ \\
\hline Transportation and Warehousing & $3(1.7 \%)$ & $7(2.1 \%)$ & $6(1.7 \%)$ & $2(2.0 \%)$ & $18(1.9 \%)$ \\
\hline Unemployed & $0(0.0 \%)$ & $7(2.1 \%)$ & $16(4.6 \%)$ & $2(2.0 \%)$ & $25(2.6 \%)$ \\
\hline Utilities & $1(0.6 \%)$ & $0(0.0 \%)$ & $0(0.0 \%)$ & $0(0.0 \%)$ & $1(0.1 \%)$ \\
\hline Wholesale Trade & $0(0.0 \%)$ & $1(0.3 \%)$ & $0(0.0 \%)$ & $0(0.0 \%)$ & $1(0.1 \%)$ \\
\hline No Response & $6(3.3 \%)$ & $22(6.6 \%)$ & $0(0.0 \%)$ & $0(0.0 \%)$ & $28(2.9 \%)$ \\
\hline Total & $180(100 \%)$ & $330(100 \%)$ & $350(100 \%)$ & $101(100 \%)$ & $961(100 \%)$ \\
\hline \multicolumn{6}{|l|}{ Years in Current Residence } \\
\hline Mean (sd) & $19.8(18.7)$ & $19.8(17.7)$ & $18(15.2)$ & $15.1(16)$ & $18.7(16.9)$ \\
\hline Minimum & 0 & 0 & 0 & 0 & 0 \\
\hline Median & 15 & 16 & 15 & 10 & 15 \\
\hline Maximum & 81 & 84 & 75 & 73 & 84 \\
\hline No Response & 1 & 1 & 1 & 0 & 3 \\
\hline
\end{tabular}




\begin{tabular}{|c|c|c|c|c|c|}
\hline Variable & $\begin{array}{l}\text { City } \\
\text { Huacho }\end{array}$ & Lima & Iquitos & Nauta & Total \\
\hline \multicolumn{6}{|l|}{ Last Move } \\
\hline Never moved & $48(26.7 \%)$ & $75(22.7 \%)$ & $57(16.3 \%)$ & $13(12.9 \%)$ & $193(20.1 \%)$ \\
\hline Same Neighborhood & $0(0.0 \%)$ & $35(10.6 \%)$ & $50(14.3 \%)$ & $2(2 \%)$ & $42(4.4 \%)$ \\
\hline Same City & $63(35 \%)$ & $122(37.0 \%)$ & $185(52.9 \%)$ & $27(26.7 \%)$ & $397(41.3 \%)$ \\
\hline Urban to Urban & $29(16.1 \%)$ & $36(10.9 \%)$ & $44(12.6 \%)$ & $21(20.8 \%)$ & $130(13.5 \%)$ \\
\hline Rural to Urban & $27(15 \%)$ & $19(5.8 \%)$ & $51(14.6 \%)$ & $36(35.6 \%)$ & $133(13.9 \%)$ \\
\hline International & $0(0.0 \%)$ & $8(2.4 \%)$ & $0(0.0 \%)$ & $0(0.0 \%)$ & $8(00.8 \%)$ \\
\hline No Response & $13(7.2 \%)$ & $35(10.6 \%)$ & $8(2.3 \%)$ & $2(2 \%)$ & $58(6.0 \%)$ \\
\hline Total & $180(100 \%)$ & $330(100 \%)$ & $350(100 \%)$ & $101(100 \%)$ & $961(100 \%)$ \\
\hline \multicolumn{6}{|l|}{ Activities Outside } \\
\hline Exercise & $32(17.8 \%)$ & $61(18.4 \%)$ & $100(28.6 \%)$ & $35(34.7 \%)$ & $228(23.7 \%)$ \\
\hline Extractive & $5(2.8 \%)$ & $11(3.3 \%)$ & $6(1.7 \%)$ & $8(7.9 \%)$ & $30(3.1 \%)$ \\
\hline Recreation & $102(56.7 \%)$ & $232(70.3 \%)$ & $199(56.9 \%)$ & $42(41.6 \%)$ & $575(59.8 \%)$ \\
\hline Work & $14(7.8 \%)$ & $11(3.3 \%)$ & $26(7.4 \%)$ & $15(14.9 \%)$ & $66(6.9 \%)$ \\
\hline Other & $0(0.0 \%)$ & $0(0.0 \%)$ & $1(0.3 \%)$ & $0(0.0 \%)$ & $1(0.1 \%)$ \\
\hline None & $29(16.1 \%)$ & $36(10.8 \%)$ & $35(10.0 \%)$ & $8(7.9 \%)$ & $108(11.2 \%)$ \\
\hline No Response & $9(5.0 \%)$ & $10(3.0 \%)$ & $0(0.0 \%)$ & $0(0.0 \%)$ & $19(2 \%)$ \\
\hline Total (Responses/Individuals) & $191 / 180$ & $361 / 330$ & $367 / 350$ & $108 / 101$ & $1027 / 961$ \\
\hline \multicolumn{6}{|l|}{ Hours Outside } \\
\hline None & $29(16.1 \%)$ & $36(10.1 \%)$ & $35(10.0 \%)$ & $8(7.9 \%)$ & $108(11.2 \%)$ \\
\hline Few (1-4) & $72(40 \%)$ & $120(36.4 \%)$ & $163(46.6 \%)$ & $39(38.6 \%)$ & $394(41 \%)$ \\
\hline Regular (4-10) & $34(18.9 \%)$ & $104(31.5 \%)$ & $104(29.7 \%)$ & $36(35.6 \%)$ & $278(29 \%)$ \\
\hline Many $(10+)$ & $40(22.2 \%)$ & $70(21.1 \%)$ & $46(13.1 \%)$ & $18(17.8 \%)$ & $174(18.1 \%)$ \\
\hline No Response & $5(2.8 \%)$ & $0(0.0 \%)$ & $2(0.6 \%)$ & $0(0.0 \%)$ & $7(0.7 \%)$ \\
\hline Total & $180(100 \%)$ & $330(100 \%)$ & $350(100 \%)$ & $101(100 \%)$ & $961(100 \%)$ \\
\hline
\end{tabular}


Table A2.2. Table summarizing all response variables from the survey by city, and then in total. For categorical variables raw numbers are presented with their proportion of the group in parenthesis. For quantitative variables, distribution parameters minimum, mean, standard deviation, median, and maximum are presented for each group. 963 individuals were surveyed in total.

\begin{tabular}{|c|c|c|c|c|c|}
\hline Variable & $\begin{array}{l}\text { City } \\
\text { Huacho }\end{array}$ & Lima & Iquitos & Nauta & Total \\
\hline \multicolumn{6}{|l|}{ Engagement } \\
\hline Has Pets & $88(49.4 \%)$ & $167(50.8 \%)$ & $208(59.4 \%)$ & $48(47.5 \%)$ & $511(53.3 \%)$ \\
\hline No Pets & $90(50.6 \%)$ & $162(49.2 \%)$ & $142(40.6 \%)$ & $53(52.5 \%)$ & 447 (46.7\%) \\
\hline Has Garden & $47(26.4 \%)$ & $96(29.5 \%)$ & $202(57.7 \%)$ & $65(64.4 \%)$ & $410(42.9 \%)$ \\
\hline No Garden & $131(73.6 \%)$ & $231(70.5 \%)$ & $148(42.3 \%)$ & $36(35.6 \%)$ & $546(57.1 \%)$ \\
\hline \multicolumn{6}{|l|}{ \#Garden Species } \\
\hline Mean (sd) & $0.5(1)$ & $0.6(1.3)$ & $1.6(1.6)$ & $2.8(2.1)$ & $1.1(1.6)$ \\
\hline minimum & 0 & 0 & 0 & 0 & 0 \\
\hline median & 0 & 0 & 1 & 3 & 0 \\
\hline maximum & 5 & 8 & 7 & 10 & 10 \\
\hline No response & $2(1.11 \%)$ & $10(3.01 \%)$ & $148(42.3 \%)$ & $36(35.6 \%)$ & $196(20.35 \%)$ \\
\hline \multicolumn{6}{|l|}{ Perception } \\
\hline Sees birds & $173(96.7 \%)$ & $318(96.1 \%)$ & $332(94.9 \%)$ & $91(90.1 \%)$ & $914(95.1 \%)$ \\
\hline Does not see birds & $6(3.4 \%)$ & $13(3.9 \%)$ & $18(5.1 \%)$ & $10(9.9 \%)$ & $47(4.9 \%)$ \\
\hline Not sure & $10(5.8 \%)$ & $12(3.7 \%)$ & $5(1.4 \%)$ & $5(5.0 \%)$ & $32(3.4 \%)$ \\
\hline Low biodiversity & $107(61.5 \%)$ & $173(53.2 \%)$ & $257(73.6 \%)$ & $71(70.3 \%)$ & $608(64.1 \%)$ \\
\hline Normal biodiversity & $40(23.0 \%)$ & $101(31.1 \%)$ & $72(20.6 \%)$ & $18(17.8 \%)$ & $231(24.3 \%)$ \\
\hline High biodiversity & $17(9.8 \%)$ & $39(12.0 \%)$ & $15(4.3 \%)$ & $7(6.9 \%)$ & $78(8.2 \%)$ \\
\hline No response & $6(3.3 \%)$ & $7(2.1 \%)$ & $1(0.29 \%)$ & $0(0 \%)$ & $14(1.45 \%)$ \\
\hline \multicolumn{6}{|l|}{ \#Estimated Species } \\
\hline Mean (sd) & $4.3(8.5)$ & $4.6(6.7)$ & $4.4(3.5)$ & $4.6(5.5)$ & $4.5(6)$ \\
\hline minimum & 0 & 0 & 0 & 0 & 0 \\
\hline median & 2.5 & 3 & 4 & 4 & 3.5 \\
\hline maximum & 100 & 100 & 25 & 50 & 100 \\
\hline No response & $0(0 \%)$ & $0(0 \%)$ & $0(0 \%)$ & $0(0 \%)$ & $0(0 \%)$ \\
\hline
\end{tabular}




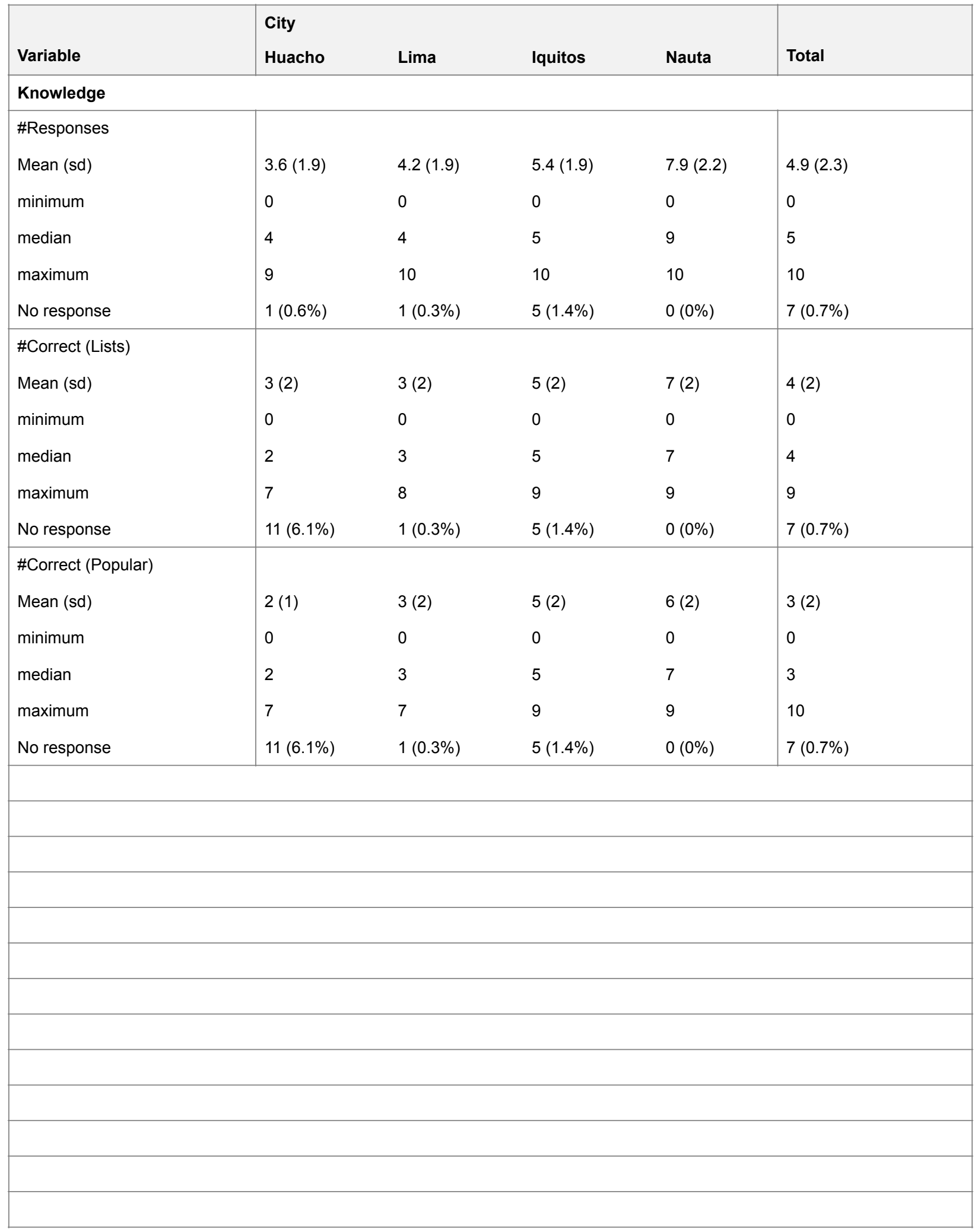




\begin{tabular}{|c|c|c|c|c|c|}
\hline Variable & $\begin{array}{l}\text { City } \\
\text { Huacho }\end{array}$ & Lima & Iquitos & Nauta & Total \\
\hline \multicolumn{6}{|l|}{ Curiosity } \\
\hline More Info - Yes & $135(75 \%)$ & $246(74.6 \%)$ & $287(82 \%)$ & $92(91.1 \%)$ & $760(79.1 \%)$ \\
\hline More Info - No & $45(25 \%)$ & $83(25.4 \%)$ & $63(18 \%)$ & $9(8.9 \%)$ & $200(20.9 \%)$ \\
\hline \multicolumn{6}{|l|}{ \#Categories } \\
\hline Mean (sd) & $1.1(0.9)$ & $1.16(1)$ & $1.2(1)$ & $1.4(1.1)$ & $1.2(1)$ \\
\hline minimum & 0 & 0 & 0 & 0 & 0 \\
\hline median & 1 & 1 & 1 & 1 & 1 \\
\hline maximum & 5 & 6 & 4 & 5 & 6 \\
\hline No response & $0(0 \%)$ & $1(0.3 \%)$ & $0(0 \%)$ & $0(0 \%)$ & $1(0.1 \%)$ \\
\hline Birdlndirect & $15(8.3 \%)$ & $26(7.8 \%)$ & $59(16.9 \%)$ & $13(12.9 \%)$ & $113(11.7 \%)$ \\
\hline Birdlntrinsic & $86(47.8 \%)$ & $184(55.8 \%)$ & $222(63.4 \%)$ & $66(65.3 \%)$ & $558(58 \%)$ \\
\hline HumanAesthetic & $1(0.6 \%)$ & $3(0.9 \%)$ & $3(0.9 \%)$ & $0(0 \%)$ & $7(0.7 \%)$ \\
\hline HumanDirect & $30(16.7 \%)$ & $53(16 \%)$ & $19(5.4 \%)$ & $10(9.9 \%)$ & $112(11.6 \%)$ \\
\hline HumanIndirect & $5(2.8 \%)$ & $6(1.8 \%)$ & $3(0.9 \%)$ & $8(7.9 \%)$ & $22(2.3 \%)$ \\
\hline HumanIntrinsic & $15(8.3 \%)$ & $23(7.0 \%)$ & $20(5.7 \%)$ & $11(10.9 \%)$ & $69(7.2 \%)$ \\
\hline HumanRecreational & $4(2.2 \%)$ & $6(1.8 \%)$ & $3(0.9 \%)$ & $2(2 \%)$ & $15(1.6 \%)$ \\
\hline No Response & $47(26.1 \%)$ & $85(25.8 \%)$ & $84(24 \%)$ & $16(15.8 \%)$ & $232(24.1 \%)$ \\
\hline Responses/Individuals & $207 / 180$ & $386 / 330$ & $413 / 350$ & $126 / 101$ & $1128 / 961$ \\
\hline
\end{tabular}


Table A2.3. Table summarizing all environmental variables from the survey by city, and then in total. Distribution parameters minimum, mean, standard deviation, median, and maximum are presented for each group. There were 97 sites in total.

\begin{tabular}{|c|c|c|c|c|c|}
\hline Variable & $\begin{array}{l}\text { City } \\
\text { Huacho }\end{array}$ & Lima & Iquitos & Nauta & Total \\
\hline \multicolumn{6}{|c|}{ Land Cover Metrics } \\
\hline \multicolumn{6}{|l|}{ Local Tree Cover } \\
\hline Mean (sd) & $7 \%(6 \%)$ & $14 \%(15 \%)$ & $13 \%(9 \%)$ & $28 \%(10 \%)$ & $10 \%(10 \%)$ \\
\hline minimum & $0 \%$ & $1 \%$ & $5 \%$ & $10 \%$ & $0 \%$ \\
\hline median & $5 \%$ & $10 \%$ & $10 \%$ & $30 \%$ & $10 \%$ \\
\hline maximum & $20 \%$ & $70 \%$ & $40 \%$ & $40 \%$ & $70 \%$ \\
\hline Number of sites & 18 & 34 & 35 & 10 & 97 \\
\hline \multicolumn{6}{|c|}{ Local Grass Cover } \\
\hline Mean (sd) & $5 \%(5 \%)$ & $10 \%(7 \%)$ & $14 \%(8 \%)$ & $20 \%(8 \%)$ & $10 \%(10 \%)$ \\
\hline minimum & $0 \%$ & $0 \%$ & $0 \%$ & $10 \%$ & $0 \%$ \\
\hline median & $4 \%$ & $10 \%$ & $15 \%$ & $20 \%$ & $10 \%$ \\
\hline maximum & $15 \%$ & $20 \%$ & $30 \%$ & $35 \%$ & $30 \%$ \\
\hline Number of sites & 18 & 34 & 35 & 10 & 97 \\
\hline \multicolumn{6}{|c|}{ Local Building Cover } \\
\hline Mean (sd) & $59 \%(16 \%)$ & $59 \%(20 \%)$ & $57 \%(17 \%)$ & $29 \%(15 \%)$ & $60 \%(20 \%)$ \\
\hline minimum & $30 \%$ & $0 \%$ & $20 \%$ & $10 \%$ & $0 \%$ \\
\hline median & $58 \%$ & $62 \%$ & $60 \%$ & $25 \%$ & $60 \%$ \\
\hline maximum & $85 \%$ & $85 \%$ & $85 \%$ & $60 \%$ & $80 \%$ \\
\hline Number of sites & 18 & 34 & 35 & 10 & 97 \\
\hline \multicolumn{6}{|c|}{ Neighborhood Tree Cover } \\
\hline Mean (sd) & $4 \%(3 \%)$ & $8 \%(4 \%)$ & $11 \%(6 \%)$ & $24 \%(8 \%)$ & $10 \%(10 \%)$ \\
\hline minimum & $0 \%$ & $2 \%$ & $1 \%$ & $10 \%$ & $0 \%$ \\
\hline median & $4 \%$ & $5 \%$ & $10 \%$ & $25 \%$ & $10 \%$ \\
\hline maximum & $10 \%$ & $20 \%$ & $25 \%$ & $35 \%$ & $30 \%$ \\
\hline Number of sites & 18 & 34 & 35 & 10 & 97 \\
\hline \multicolumn{6}{|c|}{ Neighborhood Grass Cover } \\
\hline Mean (sd) & $8 \%(6 \%$ & $7 \%(3 \%)$ & $16 \%(10 \%)$ & $21 \%(8 \%)$ & $10 \%(10 \%)$ \\
\hline minimum & $0 \%$ & $0 \%$ & $3 \%$ & $10 \%$ & $0 \%$ \\
\hline median & $6 \%$ & $10 \%$ & $15 \%$ & $20 \%$ & $10 \%$ \\
\hline
\end{tabular}




\begin{tabular}{|c|c|c|c|c|c|}
\hline Variable & $\begin{array}{l}\text { City } \\
\text { Huacho }\end{array}$ & Lima & Iquitos & Nauta & Total \\
\hline maximum & $20 \%$ & $10 \%$ & $40 \%$ & $35 \%$ & $40 \%$ \\
\hline Number of sites & 18 & 34 & 35 & 10 & 97 \\
\hline \multicolumn{6}{|c|}{ Neighborhood Building Cover } \\
\hline Mean (sd) & $54 \%(17 \%)$ & $66 \%(9 \%)$ & $53 \%(16 \%)$ & $25 \%(9 \%)$ & $60 \%(20 \%)$ \\
\hline minimum & $30 \%$ & $40 \%$ & $15 \%$ & $10 \%$ & $10 \%$ \\
\hline median & $50 \%$ & $66 \%$ & $60 \%$ & $28 \%$ & $60 \%$ \\
\hline maximum & $80 \%$ & $80 \%$ & $80 \%$ & $40 \%$ & $80 \%$ \\
\hline Number of sites & 18 & 34 & 35 & 10 & 97 \\
\hline \multicolumn{6}{|c|}{ Nearest Landmark Metrics } \\
\hline \multicolumn{6}{|c|}{ Distance to Park (m) } \\
\hline Mean (sd) & $121.21(185)$ & $77.89(133)$ & $109.22(113)$ & $52.36(55)$ & $94.6(132.3)$ \\
\hline minimum & 0 & 0 & 6.1 & 6.1 & 0 \\
\hline median & 21.34 & 12.5 & 64.9 & 26.55 & 33.8 \\
\hline maximum & 708.11 & 627.64 & 439.4 & 142.6 & 708.1 \\
\hline Number of sites & 18 & 34 & 35 & 10 & 97 \\
\hline \multicolumn{6}{|c|}{ Distance to City Center (m) } \\
\hline Mean (sd) & $1581.6(795)$ & 7901.69 (4049) & $3564.1(2194)$ & $892.9(622)$ & $4441.2(3854.6)$ \\
\hline minimum & 0 & 861 & 510.2 & 34.1 & 0 \\
\hline median & 1641.53 & 7346.7 & 3057.8 & 789.35 & 3009.5 \\
\hline maximum & 2639.32 & 199955.9 & 9221.5 & 1850.7 & 19955.9 \\
\hline Number of sites & 18 & 34 & 35 & 10 & 97 \\
\hline \multicolumn{6}{|c|}{ Distance to Water (m) } \\
\hline Mean (sd) & $1027(522)$ & $2508.27(1727)$ & $819.17(491)$ & $157.69(110)$ & $1381.6(1380.5)$ \\
\hline minimum & 52.43 & 191.72 & 71.9 & 17.1 & 17.1 \\
\hline median & 1031.59 & 2349.64 & 804.5 & 130.6 & 976.9 \\
\hline maximum & 1915.12 & 6035.04 & 2237 & 368.2 & 6035 \\
\hline Number of sites & 18 & 34 & 35 & 10 & 97 \\
\hline \multicolumn{6}{|c|}{ Bird Biodiversity Metrics } \\
\hline \multicolumn{6}{|l|}{ Species Richness } \\
\hline Mean (sd) & $11.5(4.15)$ & $14.44(4.18)$ & $21.03(6.52)$ & $23.9(4.12)$ & $17.2(6.7)$ \\
\hline minimum & 5 & 6 & 3 & 17 & 3 \\
\hline median & 11.5 & 14.5 & 20 & 24.5 & 17 \\
\hline
\end{tabular}




\begin{tabular}{|c|c|c|c|c|c|}
\hline Variable & $\begin{array}{l}\text { City } \\
\text { Huacho }\end{array}$ & Lima & Iquitos & Nauta & Total \\
\hline maximum & 20 & 21 & 35 & 30 & 35 \\
\hline Number of sites & 18 & 34 & 35 & 10 & 97 \\
\hline \multicolumn{6}{|c|}{ Simpson Evenness } \\
\hline Mean (sd) & $0.06(0.02)$ & $0.05(0.01)$ & $0.05(0.07)$ & $0.03(0.01)$ & $0.1(0)$ \\
\hline minimum & 0.03 & 0.03 & 0.02 & 0.03 & 0 \\
\hline median & 0.06 & 0.05 & 0.03 & 0.03 & 0 \\
\hline maximum & 0.11 & 0.09 & 0.4 & 0.05 & 0.4 \\
\hline Number of sites & 18 & 34 & 35 & 10 & 97 \\
\hline \multicolumn{6}{|c|}{ Average \# of Individuals } \\
\hline Mean (sd) & $35.72(17.5)$ & $41.07(29.1)$ & $34.55(11.7)$ & $50.04(23.8)$ & $38.6(21.7)$ \\
\hline minimum & 6.25 & 29.13 & 18.8 & 15.4 & 6.2 \\
\hline median & 34.88 & 13.25 & 31 & 44.9 & 33 \\
\hline maximum & 83.25 & 32 & 62.6 & 89 & 127.8 \\
\hline Number of sites & 18 & 34 & 35 & 10 & 97 \\
\hline
\end{tabular}




\section{Appendix 3.}

PCA results

Table A3.1. PCA loadings (rounded to 2 decimal places) for each environmental variable used. All shaded cells correspond to either the two highest or two lowest loadings for respective dimension. Those shaded in green indicate variables associated with "greenspace", in grey associated with "greyspace" or "concrete cover", and in beige associated with "dirt." In parentheses, the percent of variance explained by the respective dimension.

\begin{tabular}{|l|c|c|c|c|}
\hline Environmental Variable & $\begin{array}{c}\text { Dim. 1 } \\
\mathbf{( 3 1 . 6 \% )}\end{array}$ & $\begin{array}{c}\text { Dim. 2 } \\
\mathbf{( 1 6 . 5 \% )}\end{array}$ & $\begin{array}{c}\text { Dim. 3 } \\
\mathbf{( 1 0 \% )}\end{array}$ & $\begin{array}{c}\text { Dim. 4 } \\
\mathbf{( 8 . 7 \% )}\end{array}$ \\
\hline LOC_Tree & 0.31 & 0.22 & 0.16 & -0.13 \\
\hline LOC_Grass & 0.31 & 0.22 & 0.14 & 0.08 \\
\hline LOC_Asphalt & -0.19 & 0.24 & -0.12 & -0.39 \\
\hline LOC_Building & -0.35 & 0.01 & -0.28 & 0.31 \\
\hline LOC_Dirt & 0.09 & -0.47 & 0.29 & -0.22 \\
\hline NEI_Tree & 0.37 & 0.13 & -0.04 & 0.02 \\
\hline NEI_Grass & 0.35 & 0.03 & -0.02 & 0.12 \\
\hline NEI_Asphalt & -0.23 & 0.35 & 0.10 & -0.28 \\
\hline NEI_Building & -0.36 & 0.18 & 0.09 & 0.19 \\
\hline NEI_Dirt & 0.032 & -0.49 & 0.20 & -0.30 \\
\hline Distance from Park & -0.01 & -0.34 & -0.27 & 0.43 \\
\hline Distance from Water & -0.22 & 0.13 & 0.54 & 0.14 \\
\hline Distance from Center & -0.02 & 0.09 & 0.53 & 0.32 \\
\hline Observed Species & 0.33 & 0.15 & -0.22 & 0.22 \\
\hline Simpson Evenness & -0.14 & -0.08 & 0.01 & -0.24 \\
\hline Avg. \# Individual Birds & 0.13 & 0.20 & -0.26 & -0.22 \\
\hline
\end{tabular}

\section{Interpretation of PCA results:}

Dimension 2 (PC2) suggested a gradient of greenspace versus dirt open area. Dimensions 3 and 4 were less clearly interpreted, although they seem to be related to distance from the center of the city (PC3) and distance from the nearest park (PC4). The four cities displayed little differences along PC2, except for Huacho. The variables measured through bird surveys had less clear associations with the different dimensions. Observed species richness has relatively strong associations with dimensions 2,3 , and 4 (more dirt, less species; further away from center, less species; further away from nearest park, more species). Simpson evenness is associated with dimension 4 in the following manner: less urban, less evenness. Average number of individual birds is associated with dimension 2 such that less dirt, means more birds, and negatively associated with dimensions 3 and 4 (closer to center, more birds; in places closer to parks, more birds). 